\title{
Small Proline-Rich Repeat Protein 1A Is Expressed by Axotomized Neurons and Promotes Axonal Outgrowth
}

\author{
Iris E. Bonilla, ${ }^{*}$ Katsuhisa Tanabe, ${ }^{*}$ and Stephen M. Strittmatter \\ Department of Neurology and Section of Neurobiology, Yale University School of Medicine, New Haven, \\ Connecticut 06510
}

\begin{abstract}
The ability of neurons to regenerate an axon after injury is determined by both the surrounding environment and factors intrinsic to the damaged neuron. We have used cDNA microarrays to survey those genes induced during successful sciatic nerve regeneration. The small proline-rich repeat protein $1 \mathrm{~A}$ (SPRR1A) is not detectable in uninjured neurons but is induced by $>60$-fold after peripheral axonal damage. The protein is localized to injured neurons and axons. sprr1a is one of a group of epithelial differentiation genes, including s100c and p21/waf,
\end{abstract}

The degree of axonal regeneration in the adult nervous system plays a major role in determining clinical outcomes in a range of neurologic conditions, from spinal cord injury to brain trauma to stroke to chronic progressive multiple sclerosis. In part, factors extrinsic to the neuron, such as Nogo, neurotrophins, and glial scar tissue, regulate the extent of axonal regeneration (Schnell et al., 1994; Fu and Gordon, 1997; Fawcett and Asher, 1999; GrandPre et al., 2000; Fournier and Strittmatter, 2001; Fournier et al., 2001). In addition, it is clear that different neurons respond in various ways to the same environment and that injury induces changes in the axonal growth capacity of an injured neuron. The "conditioning" nerve lesion studies of Woolf and colleagues (Chong et al., 1999; Neumann and Woolf, 1999) showed that peripheral axotomy, but not central axotomy, generates an enhanced axonal growth state. Presumably, this is attributable to the induction of neuronal regeneration-associated genes (RAG) by peripheral axotomy.

The injured PNS undergoes a stereotypical reaction to injury characterized by Wallerian degeneration in the distal portion of the nerve (Stoll et al., 1989) and a sprouting process at the proximal site. At the molecular level, there is evidence for a coordinated neuronal gene program involved in the repair process. Previous research has identified a few components of this molecular genetic switch to axon growth, although this is likely to be a very incomplete view (for review, see Fu and Gordon, 1997; Gillen et al., 1997). In general, RAGs are also highly expressed during nervous system development, suggesting that regeneration recapitulates development.

\footnotetext{
Received Sept. 19, 2001; revised Nov. 6, 2001; accepted Nov. 27, 2001.

This work was supported by a predoctoral fellowship grant to I.B. from the National Institutes of Health (NIH) and by research grants to S.M.S. from NIH and the Christopher Reeve Paralysis Foundation. S.M.S. is an Investigator of the Patrick and Catherine Weldon Donaghue Medical Research Foundation.

*I.E.B. and K.T. contributed equally to this work.

Correspondence should be addressed to Dr. Stephen M. Strittmatter, Department of Neurology, Yale University School of Medicine, P.O. Box 208018, 333 Cedar Street, New Haven, CT 06520. E-mail: stephen.strittmatter@yale.edu.

Copyright (ㄷ) 2002 Society for Neuroscience $0270-6474 / 02 / 221303-13 \$ 15.00 / 0$
}

that are coinduced in neurons by axotomy. Overexpressed SPRR1A colocalizes with F-actin in membrane ruffles and augments axonal outgrowth on a range of substrates. In axotomized sensory neurons, reduction of SPRR1A function restricts axonal outgrowth. Neuronal SPRR1A may be a significant contributor to successful nerve regeneration.

Key words: axon regeneration; axonal growth cone; F-actin; neurite extension; S100 protein; microarray

The majority of the identified RAGs encode proteins in one of several categories: cytoskeletal proteins, neurotransmitter metabolizing enzymes, neuropeptides, cytokines, neurotrophins, and neurotrophin receptors. In particular, the changes in cytoskeletal protein expression support the notion that developmental processes are being recruited. The general trend during both development and regeneration is to upregulate tubulin (Moskowitz and Oblinger, 1995) and downregulate neurofilament proteins (Muma et al., 1990; Troy et al., 1990; Wong and Oblinger, 1990). Just as microtubules and neurofilaments are differentially regulated, classic neurotransmitter systems are downregulated after axotomy (for review, see Grafstein and McQuarrie, 1978; Gordon, 1983; Zigmond et al., 1996), whereas many neuropeptides are upregulated. Axotomy-induced neuropeptides include vasoactive intestinal peptide (Nielsch and Keen, 1989), galanin (Villar et al., 1989), and neuropeptide Y (Wakisaka et al., 1991). Neurotrophic factors and their receptors play critical roles during nervous system development, and in many cases expression is increased after nerve axotomy. Nerve growth factor (Ernfors et al., 1989), brain-derived neurotrophic factor and neurotrophin-3 (Schecterson and Bothwell, 1992; Kobayashi et al., 1996), acidic fibroblast growth factor (Elde et al., 1991), platelet-derived growth factor (Sasahara et al., 1991; Yeh et al., 1991), and neuregulin (Marchionni et al., 1993) are examples in this group.

Perhaps the prototypical example of a RAG is growthassociated protein-43 (GAP-43). Skene and Willard (1981) originally discovered GAP-43 as a rapidly transported axonal protein that is highly induced after sciatic nerve injury. GAP-43 protein is localized primarily in the axonal growth cone and is expressed during brain development. Its induction by trauma is correlated with substantial functional recovery after axonal injury (Skene and Willard, 1981; Katz et al., 1985; Skene, 1989; Gispen et al., 1991). GAP-43 plus cytoskeleton-associated protein-43 (CAP-43) overexpression supports a degree of CNS axon regeneration (Bomze et al., 2001). Although GAP-43 was first identified in a two-dimensional protein electrophoresis analysis of sciatic nerve injury (Skene and Willard, 1981), other RAGs have been identi- 
fied using differential display analysis (Kiryu et al., 1995; Su et al., 1997) and expressed-sequence-tag approaches (Tanabe et al., 1999).

We used cDNA microarrays to enhance the sensitivity of RAG identification in mouse sciatic nerve injury (Duggan et al., 1999). This approach demonstrates that SPRR1A is highly induced by peripheral axotomy. Furthermore, SPRR1A associates with F-actin in membrane ruffles and promotes neurite outgrowth.

\section{MATERIALS AND METHODS}

Surgery and harvesting of $m R N A$. Adult male C57BL/6 mice were anesthetized by intraperitoneal injection of avertin. The sciatic nerve at the midthigh level was either completely transected or crushed by compression with Dumont No. 5 forceps (Harvard Apparatus, Holiston, MA) for $30 \mathrm{sec}$. For retrograde labeling with Fluoro-Gold (Molecular Probes, Eugene, OR), the transected axons were exposed to $1 \mu \mathrm{l}$ of $1 \mathrm{mg} / \mathrm{ml}$ Fluoro-Gold at the time of the transection. Animals were killed 1 week after injury, and the ipsilateral DRGs from L3, L4, and L5 were removed into liquid nitrogen. Contralateral DRGs served as control samples. Poly(A)-positive RNA was harvested from DRGs using the Micro-Fast Track 2.0 mRNA Isolation Kit (Invitrogen, Carlsbad, CA), or total RNA was extracted with an RNA easy mini kit (Qiagen, Valencia, CA).

In spinal cord injury studies, mice were anesthetized with ketamine/ xylazine, and the spinal cord was exposed through T10 laminectomies. The spinal cord was completely transected, and $1 \mu \mathrm{l} \mathrm{of} 1 \mathrm{mg} / \mathrm{ml}$ FluoroGold solution was applied at the lesion site. The surgical site was closed, and animals were processed for biochemical or histological analysis after a 1 week survival period. Control DRG samples were taken from cervical levels and axotomized samples were taken from lumbar levels.

Microarray analysis. The mRNA from control and lesion DRG samples was reverse-transcribed in the presence of Cy3-dUTP and Cy5-dUTP to generate two distinct hybridization probes. These probes were hybridized to a cDNA microarray consisting of sequence-verified amplified PCR products selected from a Unigene mouse cDNA set spotted onto a glass matrix (Mouse GEM1, details at www.incyte.com). The normalized ratio of hybridization signal between samples to the arrayed cDNA is reported.

Northern blot analysis. Northern blots were performed as described previously (Goshima et al., 1995) using $400 \mathrm{ng}$ of Poly(A+) RNA or $2 \mu \mathrm{g}$ of total RNA from control and lesion DRG samples. Gene-specific ${ }^{32} \mathrm{P}$-labeled probes were synthesized by random priming and hybridized to membranes at $42^{\circ} \mathrm{C}$ in $10 \%$ dextran sulfate, $50 \%$ formamide, $5 \times$ standard saline phosphate/EDTA $\left(0.75 \mathrm{M} \mathrm{NaCl}, 58 \mathrm{~mm} \mathrm{NaH}_{2} \mathrm{PO}_{4}, 5 \mathrm{~mm}\right.$ EDTA, pH 7.4), and 1\% SDS. After the membranes had been washed at $42^{\circ} \mathrm{C}$ in $2 \times \mathrm{SSC}$ and $1 \%$ SDS, autoradiographs were generated.

Immunologic procedures. The SPRR1A cDNA (AA230988) was subcloned into pTrc-His (Invitrogen). Recombinant SPRR1A protein with an $\mathrm{N}$ terminal $\mathrm{His}_{6}$ tag was purified from transformed Escherichia coli on a nickel resin. Rabbits were immunized with SPRR1A-His protein. Antiserum was diluted 1:1000 for immunohistology and 1:3000 for immunoblots. Immunologic controls included preimmune serum and blockade with protein antigen. SPRR1A protein levels on immunoblots were quantified from densitometric analysis of standard curves of purified recombinant SPRR1A protein processed in parallel.

The S100C cDNA (AA253928) was subcloned into the pGEX2T vector, and glutathione $S$-transferase (GST)-S100C was purified from transformed E. coli using glutathione Sepharose. Rabbits were immunized with the GST-S100C protein, and antiserum was diluted to 1:100 for immunohistochemistry and immunoblotting.

One week after sciatic nerve transection or thoracic spinal cord transection [spinal cord injury (SCI)], mice were killed and perfused with $4 \%$ paraformaldehyde. DRGs ipsilateral (lesion) and contralateral (control) to the transected nerve or DRGs above (control) or below (lesion) the SCI were dissected, post-fixed, and frozen in embedding medium. The tissue was cryosectioned at $10-20 \mu \mathrm{m}$ and stained with anti-SPRR1A or anti-S100C antisera.

In situ hybridization. mRNA was localized in DRG sections by the digoxigenin-labeled riboprobe method (Wilkinson and Nieto, 1993; Goshima et al., 1995). Full-length antisense probes were used, and sense probes produced no signal.

COS-7 cell transfections. The full-length mouse SPRR1A (AA230988) and S100C (AA253928) cDNAs were transferred into pCDNA3.1 (Invitrogen) such that the vector encoded C-terminal Myc-tagged SPRR1A and C-terminal Myc-His-tagged S100C. COS-7 cells were transfected with pCDNA3.1-SPRR1A-Myc or pCDNA3.1-S100C-Myc-His or cotransfected with both plasmids using the Fugene method (Boehringer Mannheim, Indianapolis, IN). The cells were fixed with $4 \%$ paraformaldehyde $/ 20 \%$ sucrose after $36 \mathrm{hr}$ of transfection and stained with appropriate combinations of anti-SPRR1A $(1: 1000)$, anti-S100C $(1: 100)$, mouse monoclonal anti-His (C terminus) (1:500) (Invitrogen), rhodamine-phalloidin (1 U/ml) (Molecular Probes), FITC-anti-rabbit IgG (1:200) (Sigma, St. Louis, MO), or tetramethylrhodamine isothiocyanate-anti-mouse IgG (1:200) (Sigma). Cells were examined with a Zeiss LSM-510 confocal microscope (Zeiss, Thornwood, NY).

Actin cosedimentation assay. The actin cosedimentation protocol has been described previously (Gonzalez et al., 1998; Sakaguchi et al., 2000). Purified monomeric actin (G-actin, $25 \mu \mathrm{M}$; Cytoskeleton, Denver, CO) was incubated with recombinant SPRR1A $(200 \mathrm{nM})$, GST-S100C $(2 \mu \mathrm{M})$, or GST $(2 \mu \mathrm{M})$ in an actin polymerization buffer $(5 \mathrm{~mm}$ Tris, $\mathrm{pH} 8.0,1.0$ $\mathrm{mM} \mathrm{CaCl}_{2}, 1.0 \mathrm{~mm}$ DTT, $0.2 \mathrm{~mm}$ ATP, $100 \mathrm{~mm} \mathrm{KCl}, 2.0 \mathrm{~mm} \mathrm{MgCl}$ ) at room temperature for $60 \mathrm{~min}$. Polymerized actin was sedimented by centrifugation at $100,000 \times g$ for $1 \mathrm{hr}$. Equal volumes of the particulate and supernatant fractions were analyzed by SDS-PAGE and immunoblotting.

Herpes simplex virus preparation and protein trituration. The coding region of mouse SPRR1A was amplified by PCR with an in-frame $\mathrm{C}$-terminal Myc epitope and ligated to the pHSVprPUC vector. Similarly, the S100C coding region with a Myc tag was ligated to pHSVprPUC vector. The resulting plasmids were transfected into 2-2 cells with Fugene and then superinfected with $5 \mathrm{dl} 1.2$ herpes simplex virus (HSV) helper virus $1 \mathrm{~d}$ later as described previously (Nakamura et al., 1998; Takahashi et al., 1998, 1999). Recombinant virus was amplified through three passages and stored at $-80^{\circ} \mathrm{C}$. Freshly dissociated DRG neurons were allowed to adhere to cultured dishes for $30 \mathrm{~min}$ and then incubated with HSV preparations encoding for SPRR1A, S100C, enhanced green fluorescent protein (EGFP), or Nogo receptor. Recombinant SPRR1A and S100C protein were triturated into dissociated DRGs by repetitive pipetting in the presence of $1 \mathrm{mg} / \mathrm{ml}$ of protein as described previously (Jin and Strittmatter, 1997).

$D R G$ cultures and neurite outgrowth analysis. Embryonic day 7 (E7) chick, embryonic day 13 chick, or adult mouse DRGs were dissected and dissociated with $0.25 \%$ trypsin for $15 \mathrm{~min}$ at $37^{\circ} \mathrm{C}$. For adult mouse DRG preparations, preincubation with $1 \mathrm{mg} / \mathrm{ml}$ collagenase was included. For preconditioned adult mouse DRG cultures, sciatic nerve lesions were performed $4 \mathrm{~d}$ before death and L3-L5 DRG dissection. Dissociated cells were preplated on tissue culture-treated plastic dishes for $1 \mathrm{hr}$ at $37^{\circ} \mathrm{C}$. Nonadherent cells (predominantly neurons) were collected and plated on plastic chamber slides coated with poly-L-lysine $(100 \mu \mathrm{g}) /$ laminin $(10 \mu \mathrm{g} / \mathrm{ml})$. In some cases, the substrate was coated with 45 $\mathrm{ng} / \mathrm{mm}^{2}$ bovine CNS myelin or $34 \mathrm{ng} / \mathrm{mm}^{2}$ purified GST-Nogo-66 protein as described previously (Jin and Strittmatter, 1997; GrandPre et al., 2000; Fournier et al., 2001). After 6-36 hr, cells were fixed and stained, and neurite outgrowth was quantified. Images of each culture were captured with Olympix Software (Olympus Technologies, Melville, NY) and analyzed with Scion Image (Scion Corporation, Frederick, MD) (Jin and Strittmatter, 1997; GrandPre et al., 2000; Fournier et al., 2001). The total neurite length for each neuron was determined for 50-100 neurons in each experiment. The total number of branch points was divided by the total neurite length to obtain a branching index.

Antisense experiment. Phosphorothioate sense and antisense oligonucleotides spanning the translation initiation site (italic type) of the mouse sprrla sequence (sense, $p$-thio-ATCTAACCATGAGTTCCCAC; antisense, $p$-thio-GTGGGAACTCATGGTTAGAT) were generated. Adult mouse DRG cultures were incubated with purified oligonucleotides at concentrations of 10-50 $\mu \mathrm{M}$. Immunoblot and immunohistological analysis was performed after $36 \mathrm{hr}$ of culture.

Antibody blockade. Affinity-purified rabbit $\alpha$-SPRR1A antibody $(0.2$ $\mathrm{mg} / \mathrm{ml}$ ) was triturated into DRG neurons before plating as described for other proteins (Jin and Strittmatter, 1997). Rabbit IgG $(0.2 \mathrm{mg} / \mathrm{ml})$ was used as a control. Triturated DRG neurons were cultured for $6 \mathrm{hr}$ and then analyzed by immunohistochemistry and morphometry.

\section{RESULTS}

\section{Microarray expression profile of axonal regeneration}

An array containing 8500 cDNA species (Incyte mouse GEM) was used to analyze mRNA expression in the lumbar DRG 1 week after sciatic nerve transection. Sixteen mRNAs with greater 


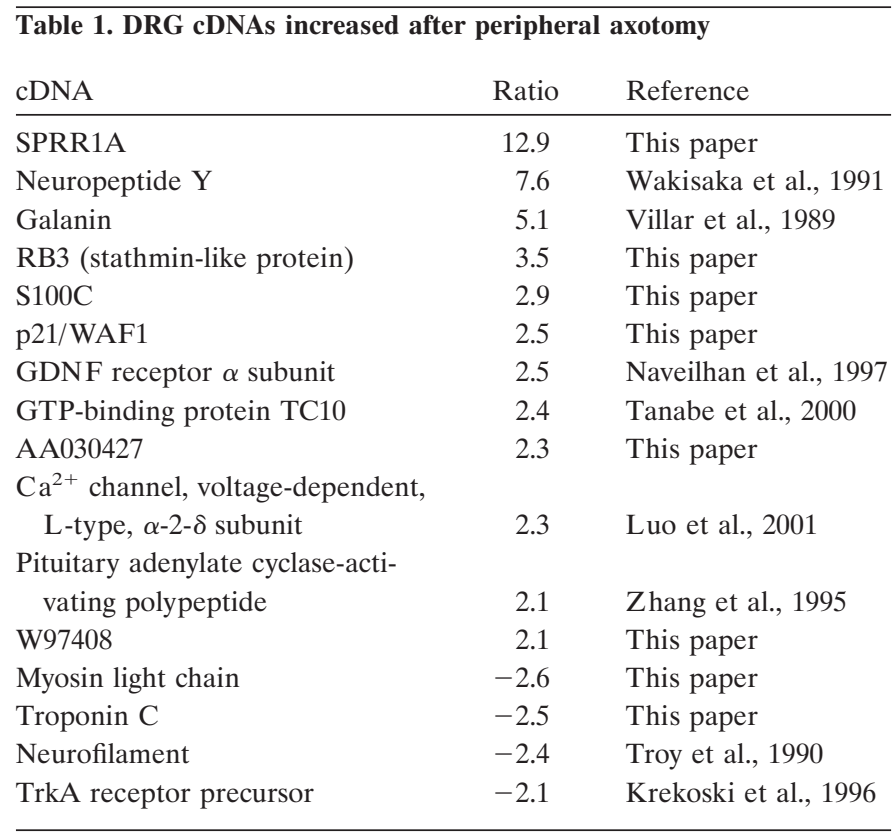

Those genes with a change in expression levels of greater than twofold 1 week after sciatic nerve transection are listed.

than twofold upregulation or downregulation were detected. Eight of these transcripts were recognized previously as being induced or repressed by nerve regeneration, including galanin, neuropeptide Y, neurofilament, glial cell line-derived neurotrophic factor (GDNF) receptor $\alpha$ subunit, pituitary adenylate cyclase-activating polypeptide, GTP-binding protein TC10, calcium channel $\alpha-2-\delta$ subunit, and trkA receptor (Table 1$)$. The results support the validity and sensitivity of this method. The eight other regulated genes include six known genes that were not recognized previously as being differentially regulated by axotomy and two novel genes.

Among the six known genes that were not recognized previously as being differentially regulated by axotomy, there were three genes sharing many common characteristics. SPRR1A, S100C, and p21/wild-type p53-activated factor 1 (WAF1) are all upregulated after UV irradiation of epithelial cells (Rosen et al., 1995). SPRR1A and S100C are induced during epithelial differentiation and are covalently cross-linked in the cornified envelope (CE) of terminally differentiated keratinocytes. Cross-linked SPRR1A and S100C are thought to contribute to the permeability barrier function of the CE. The common properties of these gene products, along with their concerted upregulation after sciatic nerve injury, raise the possibility that peripheral axonal regeneration uses a gene program shared with epithelial differentiation. For this reason, we initially focused additional study on these genes.

\section{SPRR1A is dramatically increased after sciatic nerve transection}

The transcript that showed the highest level of upregulation was sprrla ( $\geq 13$-fold by microarray) (Fig. $1 A$ ). sprrla is a member of the small, proline-rich family of genes composed of two sprr1 genes, eight sprr 2 genes, and one sprr3 gene. At the core of the SPRR1A protein is a repeating XPKXPEPC octapeptide sequence. SPRR1A expression after axotomy was unexpected, because neuronal expression of the protein has not been detected previously. Indeed, SPRR1A has been considered a highly specific marker for the differentiation of keratinocytes and squamous epithelial cells (Kartasova and van de Putte, 1988; Kartasova et al., 1988; Gibbs et al., 1993). The increased expression of sprrla detected by microarray analysis was verified by Northern blotting (Fig. 1A). sprrla mRNA levels, like gap-43 levels, are greatly increased in the axotomized DRG sample compared with the

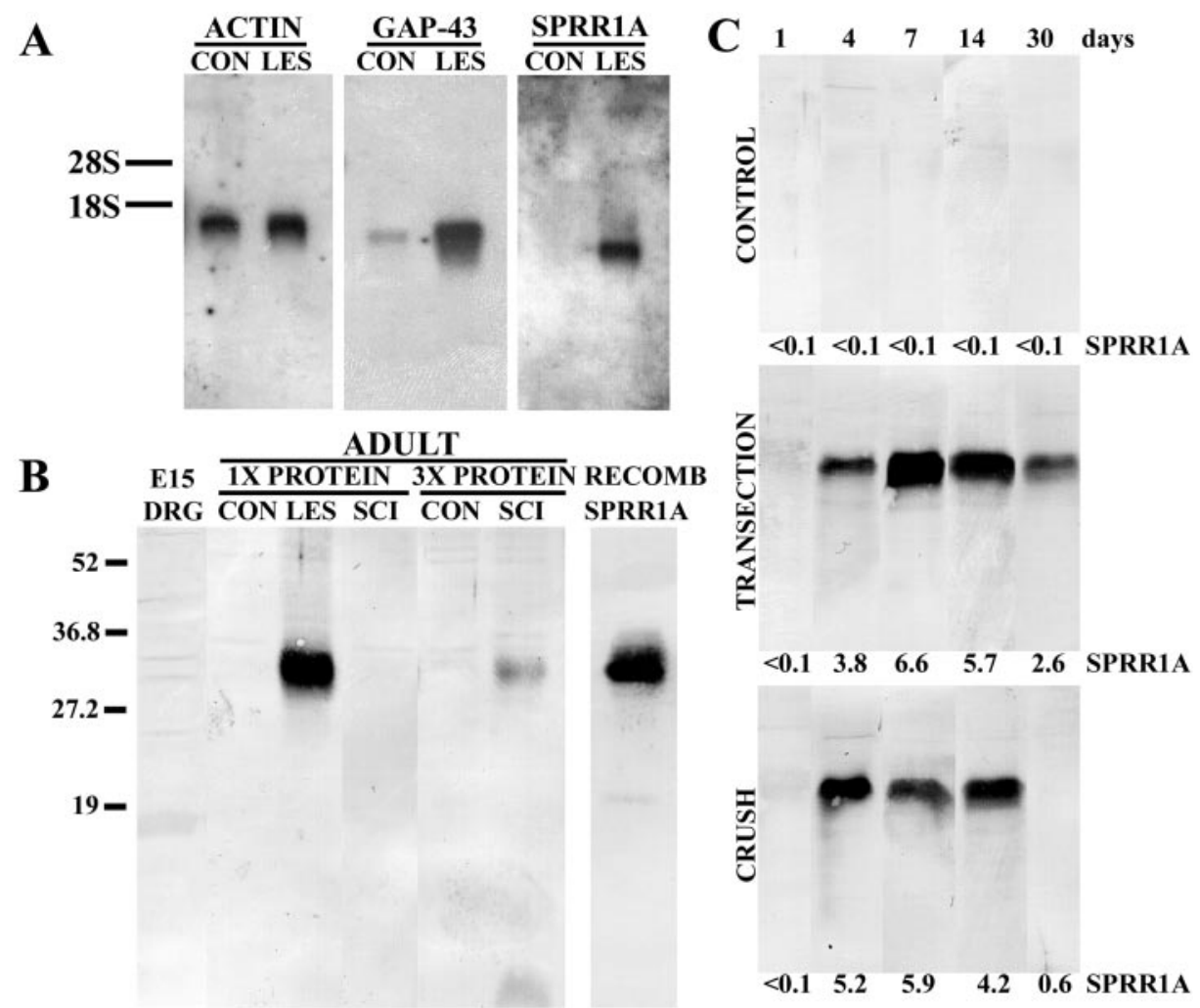

Figure 1. SPRR1A is induced in DRGs by axotomy. $A$, Northern blot analysis reveals that actin mRNA levels remain constant in lumbar DRGs 1 week after sciatic nerve lesion (LES) compared with control (CON) levels. DRGs dramatically upregulate both sprrla and gap-43 mRNA after sciatic nerve transection. Migration of $28 \mathrm{~S}$ and $18 \mathrm{~S}$ ribosomal RNA is shown at left. $B$, Immunoblots for SPRR1A protein demonstrate upregulation in adult L3-L5 DRGs $(1 X, 10 \mu \mathrm{g}$ total protein; $3 X, 30 \mu \mathrm{g}$ total protein) after transection of the ipsilateral sciatic nerve (LES) compared with unlesioned $(C O N)$ samples. SPRR1A is not detected in uninjured E15 DRG samples. There is a small but detectable increase in SPRR1A protein after thoracic SCI seen only in the $3 \mathrm{X}$ samples. Molecular weight markers are shown at left. C, DRGs contralateral to sciatic nerve axotomy do not express detectable SPRR1A by immunoblot (CONTROL, top). Nerve transection induces SPRR1A upregulation within $4 \mathrm{~d}$ after injury (middle). SPRR1A protein levels peak at 7-14 $\mathrm{d}$, with a reduction 1 month after the injury. Nerve crush induces a similar SPRR1A expression level at $7 \mathrm{~d}$, but levels decrease to baseline by 1 month (bottom). The number of days between nerve transection and animal death is shown at the top. Concentrations of SPRR1A protein in the DRG homogenates are reported at the bottom of each lane in nanograms of SPRR1A per microgram of total protein. 
control, whereas actin levels remain constant. As opposed to gap-43, no sprrla mRNA is detectable in DRGs before axotomy. SPRR1A protein levels parallel mRNA levels in lumbar DRG extracts after sciatic nerve injury (Fig. $1 B$ ). As described previously (Kartasova and van de Putte, 1988; Kartasova et al., 1988), the $18 \mathrm{kDa}$ SPRR1A protein migrates anomalously in SDSPAGE at $34 \mathrm{kDa}$ (Fig. $1 B$ ). This is most likely because of its unusual amino acid composition, consisting of $30 \%$ proline residues. Known RAGs, such as GAP-43, are expressed strongly during the axonal outgrowth period of embryonic development (Fu and Gordon, 1997; Gillen et al., 1997). No SPRR1A protein is observed, however, in E15 DRGs (Fig. 1B) or in E12 to postnatal day 4 samples (data not shown). In this regard, SPRR1A is unique among known RAGs.

The upregulation of SPRR1A in DRG neurons after peripheral axotomy raised the question of whether these neurons would react in the same manner after a lesion of their central process. To assess this question, lumbar DRGs were removed from mice 1 week after thoracic SCI, and SPRR1A protein levels were analyzed. This lesion severs the central axon of those DRG neurons contributing to the dorsal columns, a significant subset of the lumbar DRG population. The SPRR1A protein increase after central axotomy is much less robust than that observed after peripheral axotomy and is undetectable unless the gels are overloaded with protein (Fig. $1 B$ ). The limited induction with central injury resembles the pattern with GAP-43 (Kalil and Skene, 1986) and might contribute to the cause of poor CNS axon regeneration.

If SPRR1A induction after axotomy was correlated with the initial injury phase, this would suggest an immediate early gene function, whereas a correlation with the axonal regeneration phase might suggest a direct contribution to axon growth. To explore the temporal relationship between SPRR1A expression and sciatic nerve regeneration, DRGs were analyzed for SPRR1A protein at various times after resection of a piece of sciatic nerve. SPRR1A protein is not detectable $1 \mathrm{~d}$ after injury but is dramatically upregulated by $4 \mathrm{~d}$ and reaches peak levels 1-2 weeks after sciatic nerve injury (Fig. $1 C$ ). At maximal levels, SPRR1A constitutes $\sim 0.5 \%$ of total DRG protein or $6 \mathrm{ng}$ of SPRR1A per microgram of total protein based on quantitative immunoblots using purified SPRR1A as a standard. Because the detection limit in this assay is $0.1 \mathrm{ng}$ of SPRR1A per microgram of total protein, the increase in SPRR1A is $>60$-fold. SPRR1A levels are significantly reduced 1 month after injury. The decrease in SPRR1A at later times may reflect some reinnervation of appropriate and inappropriate targets with consequent downregulation of RAGs. To explore this further, we subjected another group of mice to sciatic nerve crush, which results in a similar degree of axonal damage but allows for more rapid and successful regeneration with complete functional recovery within 1 month. After midthigh sciatic nerve crush injury, DRG levels of SPRR1A protein follow a similar strong induction, but the downregulation is nearly complete at 1 month. This time course correlates well with hindlimb functional recovery after such injuries (data not shown). Thus, DRG SPRR1A expression is bidirectionally regulated by axonal injury and target innervation.

The DRG contains not only neurons but also fibroblasts, satellite cells, and Schwann cells. To assess the cellular origin of SPRR1A protein in axotomized DRGs, immunohistochemical experiments were conducted. The pattern of SPRR1A staining in DRGs is consistent with neuronal cell bodies and axonal processes (Fig. $2 A$ ). A nerve crush injury was performed to deter- mine whether regenerating axons crossing the site of injury contained SPRR1A protein. Axons in sections both proximal and distal to the crush site showed intense SPRR1A immunoreactivity, demonstrating that the protein is transported throughout the regenerating axonal process (Fig. $2 B$ ). That the stained cells are regenerating DRG neurons is clear in samples retrogradely labeled with Fluoro-Gold from the injured sciatic nerve (Fig. 2C). By two criteria, SPRR1A appears to be expressed in most, if not all, subclasses of DRG neurons. First, the vast majority of FluoroGold-positive neurons, $85 \pm 3 \%$, also exhibited SPRR1A immunoreactivity. Second, the average cell diameter of Fluoro-Goldpositive and SPRR1A-positive neurons was indistinguishable (35 $\pm 2 \mu \mathrm{m}$ vs $38 \pm 2 \mu \mathrm{m})$. Because different subsets of DRG neurons have distinct cell sizes, the observed size supports the hypothesis that SPRR1A is expressed by most axotomized DRG neurons.

SPRR1A protein localization in DRGs after spinal cord injury was examined by retrogradely labeling neuronal cell bodies with Fluoro-Gold injected at the site of injury. Low levels of SPRR1A protein were detected in DRG neurons after central axotomy (Fig. 2C), consistent with the immunoblots showing a slight increase in SPRR1A levels (Fig. 2C). The histologic studies also demonstrate that on a cell-by-cell basis, peripheral axotomy is a much stronger SPRR1A-inducing signal than is central injury.

The sciatic nerve transection injures axons from both DRG sensory neurons and spinal motoneurons. Examination of spinal cord sections reveals that retrogradely labeled axotomized motoneurons in the ventral horn exhibit SPRR1A expression to a similar extent as do DRG neurons (Fig. 2C). The contralateral ventral horn does not exhibit SPRR1A immunoreactivity. Thus, neurons situated in both the CNS and PNS strongly upregulate SPRR1A after peripheral axotomy.

\section{S100C and p21/WAF expression are increased after sciatic nerve axotomy}

The results from the microarray screen reveal a more than threefold upregulation of S100C (Table 1). S100C forms dimers and is a member of a family of small S100 proteins that exhibit EF-handtype $\mathrm{Ca}^{2+}$-binding properties. Like SPRR1A, S100C is thought to be a structural component of the CE of epithelial cells (Robinson et al., 1997). It has also been implicated in the regulation of cytoskeletal functions via $\mathrm{Ca}^{2+}$-dependent interaction with annexin I and F-actin (Naka et al., 1994; Mailliard et al., 1996; Sakaguchi et al., 2000). Other functions attributed to the S100 family include cell-cycle regulation, cell differentiation, cell growth, and metabolic control (Allen et al., 1996; Marti et al., 1996; Scotto et al., 1998).

p21/WAF1 is the third transcript induced after sciatic nerve axotomy whose expression is characterized in this study (Fig. 1B). p21, also known as WAF1, cyclin-dependent kinase-interacting protein 1, and senescent cell-derived inhibitor 1, is involved in cell-cycle regulation, cell differentiation, and tumor suppression (for review, see Cox, 1997; Gartel and Tyner, 1999). The p21 protein is a cyclin kinase inhibitor that inhibits $\mathrm{G}_{1}$ cyclin/cyclindependent kinase complexes (Harper et al., 1993; Xiong et al., 1993) and is activated by p53 (El-Deiry et al., 1993). In addition, like SPRR1A and S100C, p21 is induced by UV irradiation (Gorospe et al., 1998) and by phorbol esters (Zeng et al., 1997) in epithelial cells.

Northern blot analysis confirms the upregulation of $s 100 \mathrm{c}$ and p21/waf1 after peripheral axotomy. s100c and p21/waf1 are also expressed in DRGs at embryonic and early postnatal stages, 

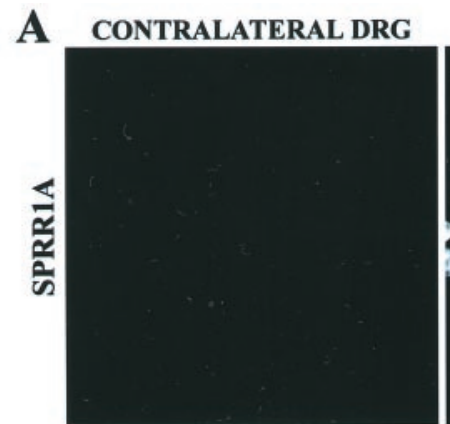

B CONTRALATERAL NERVE

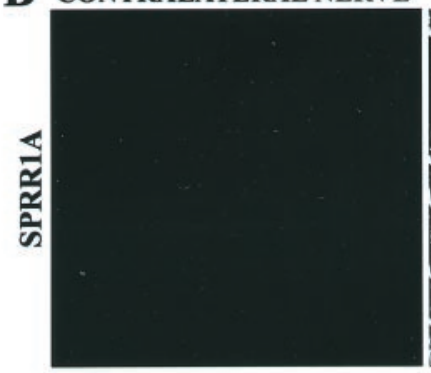



C FLUORO-GOLD
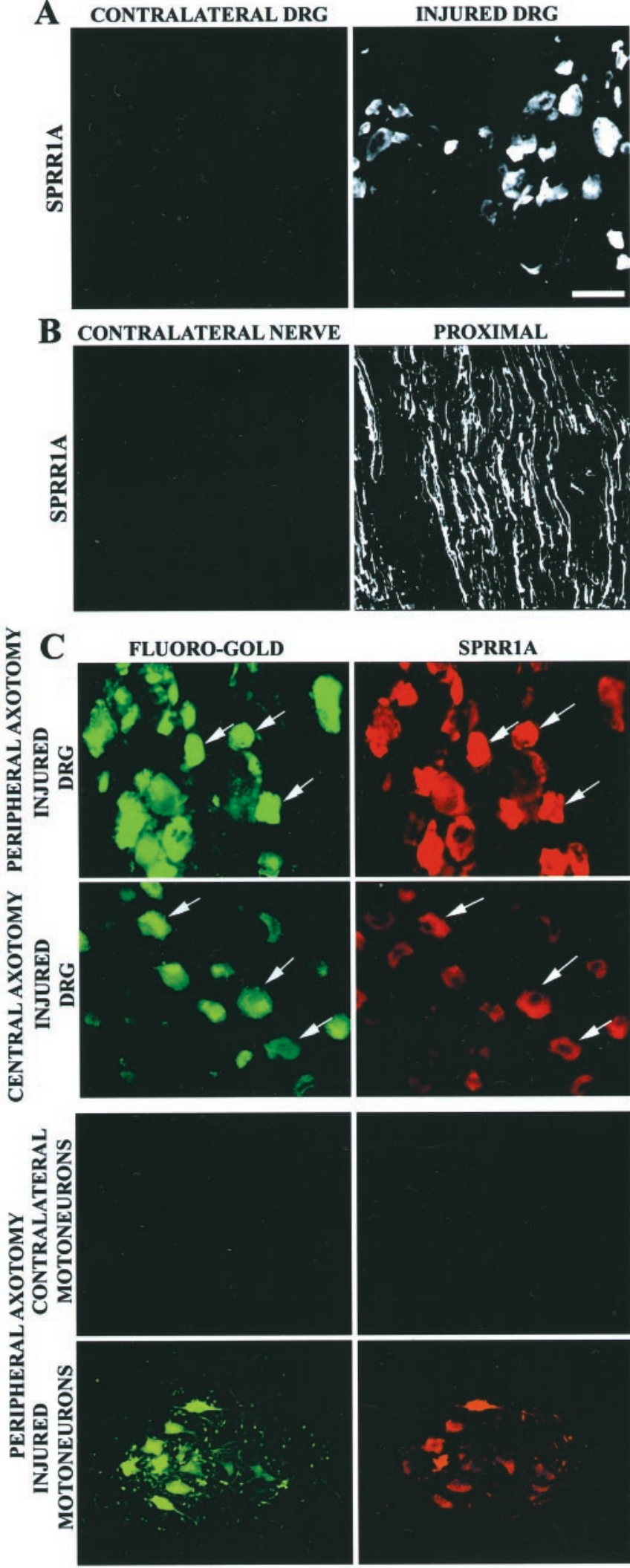

PROXIMAL
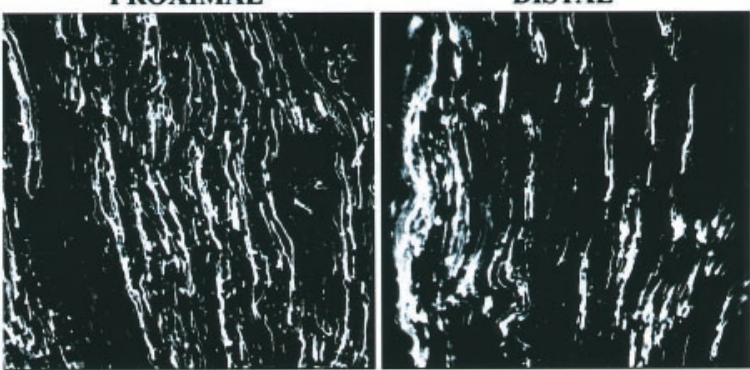

INJURED NERVE ROOT

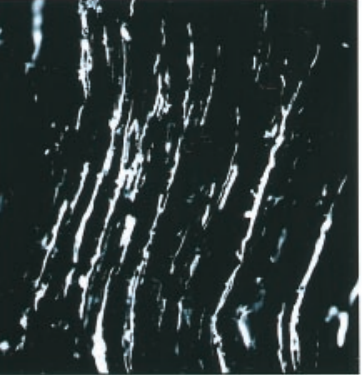

DISTAL

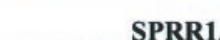

SPRR1A

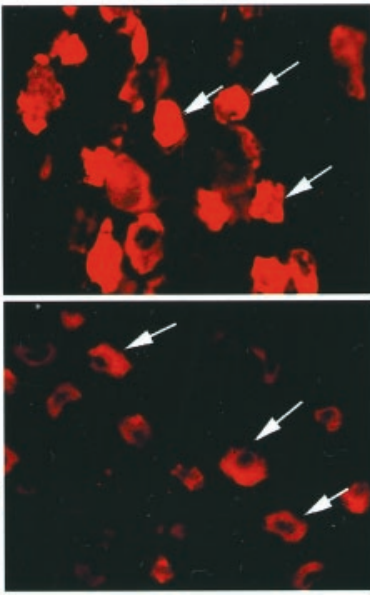

FLUORO-GOLD+SPRR1A
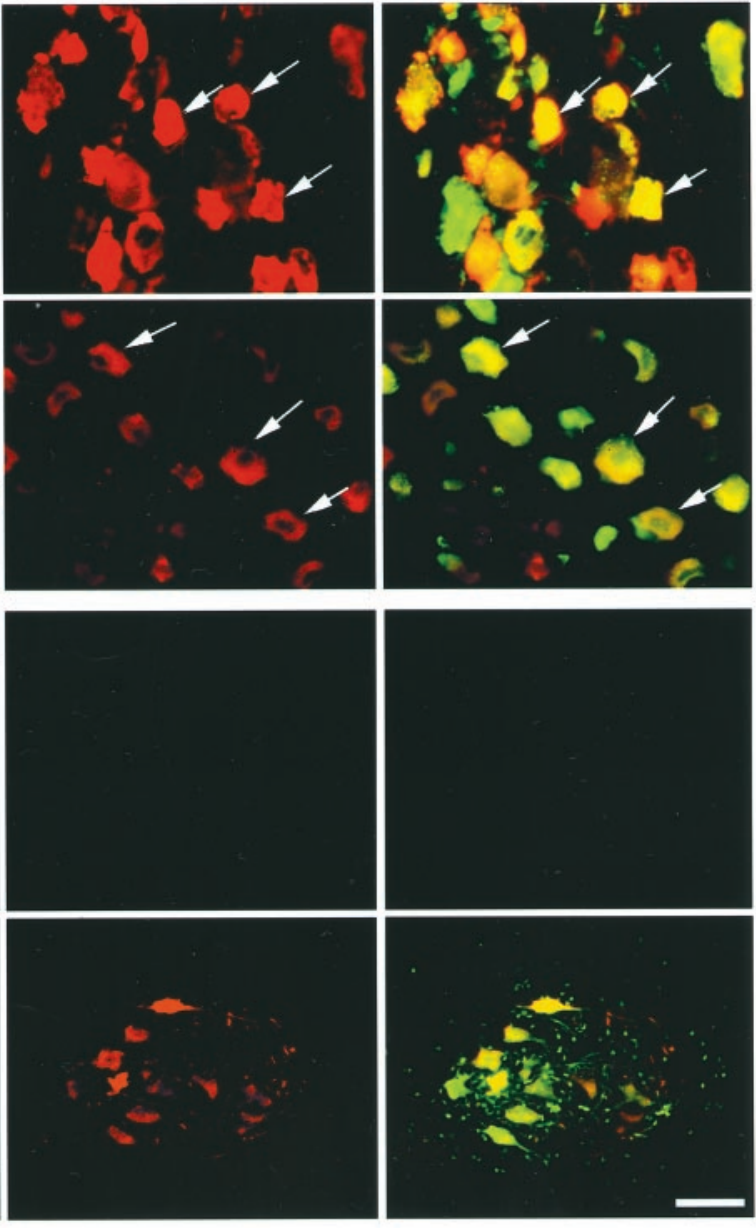

Figure 2. SPRR1A is expressed in regenerating sensory and motor neurons. $A$, SPRR1A immunofluorescence demonstrates protein in the cell bodies and axons of DRG neurons 1 week after peripheral axotomy (injured). No SPRR1A immunoreactivity can be found in adult control DRGs (contralateral). Scale bar, $50 \mu \mathrm{m}$. $B$, SPRR1A protein is distributed throughout DRG regenerating axons, as revealed by SPRR1A immunoreactivity of sciatic nerve 1 week after a crush injury. SPRR1Apositive axons were found up to $20 \mathrm{~mm}$ distal from the crush site. The protein is absent in the contralateral (uninjured) nerve. Scale bar, $100 \mu \mathrm{m}$ (from $A$ ). $C$, Intense SPRR1A protein immunoreactivity colocalizes with Fluoro-Gold retrogradely labeled sensory and motor neurons ipsilateral to a sciatic nerve transection (peripheral axotomy, arrows). SPRR1A is slightly elevated in sensory neurons 1 week after thoracic SCI (central axotomy). SPRR1A is absent from the ventral horn contralateral to a sciatic nerve transection. Scale bar: first and second rows, $50 \mu \mathrm{m}$; third and fourth rows, $100 \mu \mathrm{m}$. contrary to sprr1a but similar to gap-43 (Fig. $3 A$ ). At the protein level, S100C is elevated $4 \mathrm{~d}$ after axotomy, remains increased up to 2 weeks after injury, and returns to normal levels by 1 month (Fig. 3B), a time course similar to that of SPRR1A and GAP-43.
In the DRG homogenates composed of both neuronal and nonneuronal elements, the S100C protein level is induced by $100 \%$. The cellular identity of the cells overexpressing S100C after axotomy was investigated by in situ hybridization and immuno- 

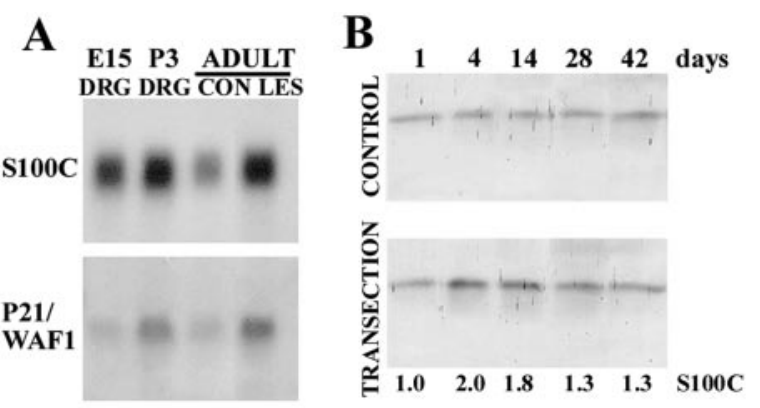

C contralateral drg
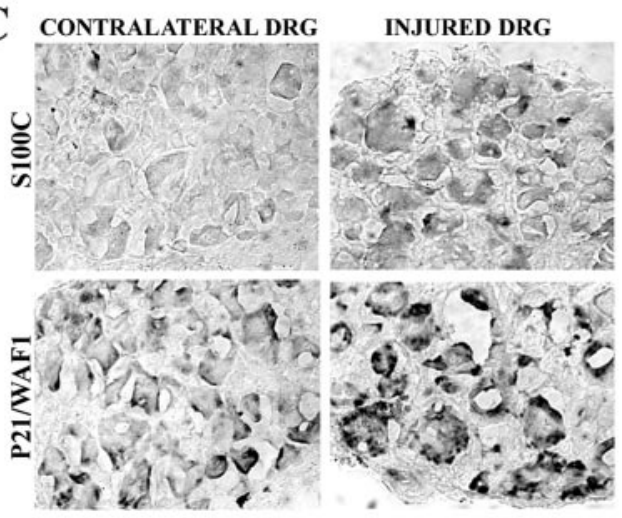

D contralateral drg

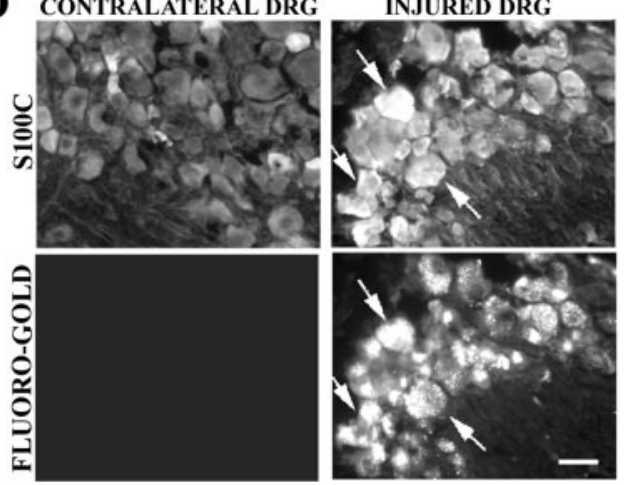

Figure 3. S100C and $\mathrm{p} 21 / \mathrm{WAF} 1$ are induced in regenerating sensory neurons by axotomy. $A$, Northern blot analysis of $s 100 c$ mRNA levels in lumbar DRGs from animals of different ages is shown. Adult DRG samples were analyzed contralateral $(C O N)$ or ipsilateral $(L E S)$ to a sciatic nerve transection 1 week before death. A clear upregulation of the transcript after axotomy is evident. p21/waf1 mRNA levels are regulated in a similar manner in the lower panel. Two micrograms of total RNA were loaded in each lane. $B, \mathrm{~S} 100 \mathrm{C}$ immunoblots demonstrate protein levels contralateral (CONTROL) or ipsilateral (TRANSECTION) to a sciatic nerve transection at the indicated times after lesion. Quantification of the relative levels of S100C protein in the axotomized DRG samples is reported at the bottom. $C$, In situ hybridization demonstrates $s 100 \mathrm{c}$ and p21/waf1 mRNA expression in lumbar DRGs contralateral or ipsilateral (injured) to sciatic nerve transection 1 week before death. $D, \mathrm{~S} 100 \mathrm{C}$ immunostaining of DRG sections that were retrogradely labeled with Fluoro-Gold demonstrates that the protein is induced selectively in neurons that underwent transection 1 week earlier at the midthigh (arrows). Scale bar, $50 \mu \mathrm{m}$.

cytological experiments. Both $s 100 c$ and $p 21$ mRNA are localized to neuronal cell bodies in the DRG by in situ hybridization experiments (Fig. 3C). Fluoro-Gold retrograde labeling of injured DRG neurons demonstrates that regenerating DRG neurons exhibit increased S100C expression (Fig. 3D). Because these neurons compose approximately one-half of the DRG cell pop- ulation, the results of Figure $3 A, C$ suggest that S100C protein levels are approximately threefold higher in axotomized neurons.

\section{SPRR1A and S100C are localized to F-actin structures}

In the CE, SPRR1A and S100C, along with other proteins, are covalently cross-linked by transglutaminases (TGases) to generate a rigid structure that alters cellular properties (Greenberg et al., 1991; Hohl et al., 1995). To consider whether SPRR1A and S100C might have a related function in neurons, we assayed SPRR1A cross-linking and TGase activity. Immunoblot experiments of protein from control and lesion DRGs revealed only monomeric SPRR1A (Fig. $1 B$ ) and no insoluble aggregated SPRR1A immunoreactivity (data not shown). Furthermore, no consistent or significant difference in DRG TGase activity between control and sciatic nerve lesion samples could be detected (data not shown). We conclude that SPRR1A and S100C do not participate in a CE-like structure in injured DRGs.

To consider alternative mechanisms of SPRR1A function, we examined the subcellular distribution of the protein, considering what is known about S100C. S100C binds to F-actin in the presence of $\mathrm{Ca}^{2+}$ and alters cytoskeletal function in nonneuronal cells (Sakaguchi et al., 2000). Because F-actin dynamics play a major role in regulating axonal growth cone motility, we hypothesized that axotomy-induced SPRR1A and S100C protein might modulate F-actin structures in concert. Transient expression of SPRR1A and S100C in non-neuronal cells allowed for a careful examination of their localization relative to F-actin. Both SPRR1A and S100C are highly concentrated in certain F-actinrich structures (Fig. $4 A-C$ ). SPRR1A immunoreactivity in COS-7 cells is enriched in serpentine structures consistent with dorsal ruffles and in leading edge ruffles. A reconstruction of a $z$-axis series from confocal microscopy verified the localization of SPRR1A to dorsal ruffles (Fig. 4D). SPRR1A protein is not localized to F-actin-positive stress fibers. The previous description of S100C affinity for F-actin is evident in our studies (Fig. $4 B$ ). Similar to SPRR1A, S100C protein is present in dorsal and leading edge ruffles. Contrary to the exclusive localization of SPRR1A in these structures, S100C also localizes to stress fibers. The presence of both SPRR1A and S100C in membrane ruffles suggests that they contribute to similar or identical subcellular structures. A direct examination of doubly transfected cells confirms that the two proteins codistribute in dorsal and leading edge ruffles. Variation in F-actin structures from cell to cell is great in these cultures, and we have not observed any pronounced shift in the type or total number of F-actin-rich structures in SPRR1Aexpressing cells.

We sought to determine whether SPRR1A was also localized to F-actin-rich regions of axonal growth cones. A recombinant HSV preparation was used to express SPRR1A in chick embryonic DRG cultures. The infected fibroblasts in these cultures exhibit an SPRR1A distribution that is essentially identical to the transfected COS-7 cells (Fig. 4B). Infected neurons exhibit SPRR1A immunoreactivity throughout their axons (Fig. $4 E$ ), similar to the axonal localization seen in tissue samples from sciatic nervetransected animals (Fig. 2). Higher magnification of well-spread axonal growth cones in these cultures reveals SPRR1A immunoreactivity colocalized with $\mathrm{F}$-actin in discrete linear ridges and aggregates in axonal growth cones. The pattern is consistent with dorsal and leading edge ruffles.

Whereas SPRR1A is colocalized with F-actin in ruffles, other F-actin-rich structures, such as stress fibers and filopodia, do not exhibit specific concentrations of SPRR1A. This suggests that 
A

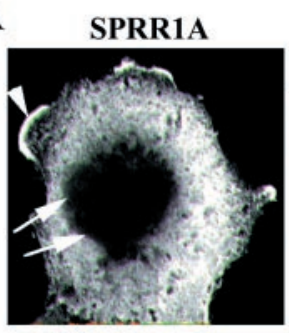

B



C
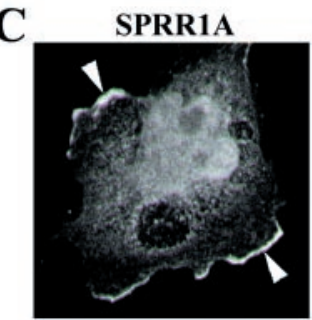

$\mathbf{E}$

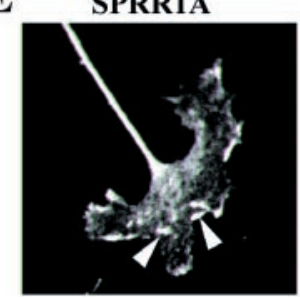

F-ACTIN

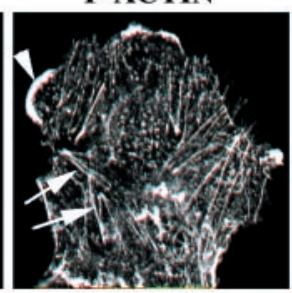

F-ACTIN
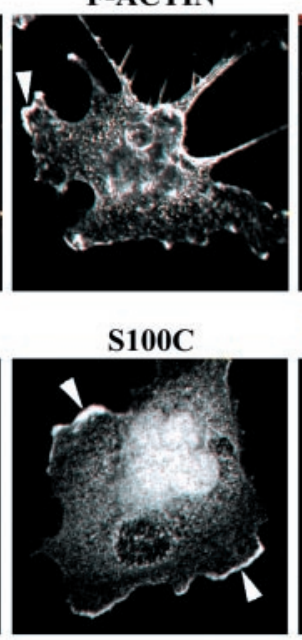

F-ACTIN



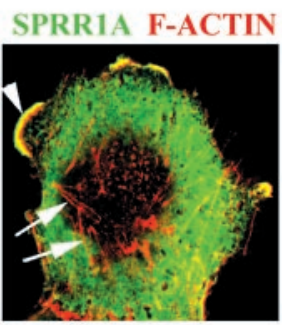

S100C F-ACTIN

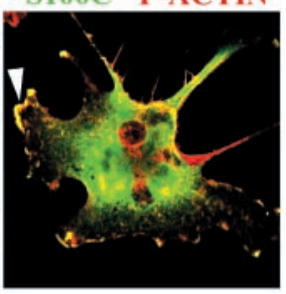

SPRR1A S100C

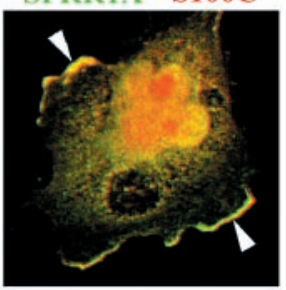

SPRR1A F-ACTIN

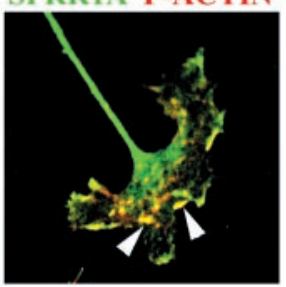

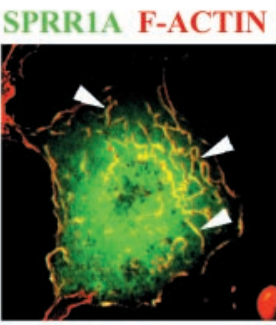

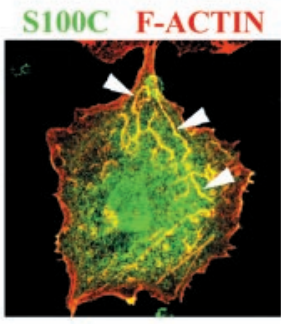

SPRR1A S100C

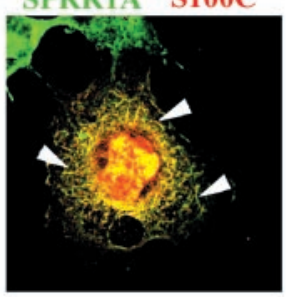

SPRR1A F-ACTIN

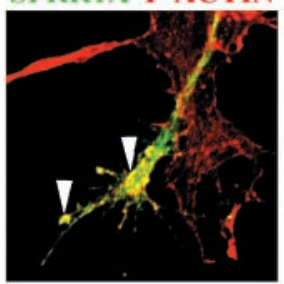

D

SPRR1A F-ACTIN
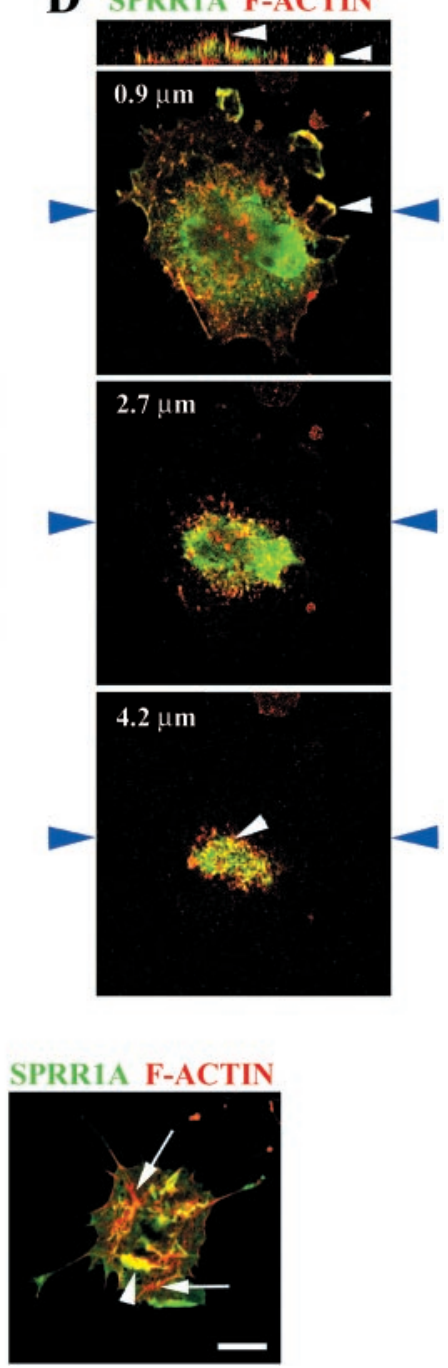

Figure 4. SPRR1A colocalization with F-actin and S100C in COS-7 cells and neuronal growth cones. $A$, COS-7 cells were transfected with pCDNA3.1-SPRR1A-Myc. SPRR1A immunoreactivity colocalizes with F-actin-rich structures, predominantly at dorsal and leading edge ruffles (arrowheads). SPRR1A is absent from actin-rich stress fibers (arrows). A-C, The left three panels show double labeling of one cell, and the extreme right panels show a different cell. B, COS-7 cells were transfected with pCDNA3.1-S100C-Myc-His. S100C immunoreactivity colocalizes with F-actin (ruffles, arrowheads). C, pCDNA3.1-SPRR1A-Myc and pDNA3.1-S100C-Myc-His were cotransfected into COS-7 cells. SPRR1A and S100C immunoreactivity codistributed at leading edge and dorsal ruffles (arrowheads). S100C was detected by staining with monoclonal anti-His antibodies. $D$, The distribution of SPRR1A and F-actin in a pDNA3.1-SPRR1A-Myc-transfected COS-7 cell is examined in three dimensions. Top, Vertical (z-axis) cross section at the level of the blue arrows for the lower three panels. The numbers on the lower three panels refer to the distance above the substrate. Note the predominant distribution of SPRR1A to dorsal and leading edge ruffles (arrowheads). A dorsal ruffle is shown to protrude into the upper region of the cell. E, Chick E7 DRG cultures were infected with HSV-SPRR1A and examined for SPRR1A and F-actin distribution 24 hr later by confocal microscopy. In axonal growth cones (left three panels show one growth cone, and the next panel shows a second growth cone) and fibroblasts (right panel), note the similar distribution of SPRR1A and F-actin in linear aggregates and ruffles (arrowheads). Other F-actin-rich structures (arrows), such as stress fibers, are not enriched in SPRR1A. Scale bar, $50 \mu \mathrm{m}$.

SPRR1A does not bind directly to F-actin but rather to actinassociated protein(s) enriched in ruffles. To verify whether or not SPRR1A is able to bind F-actin directly, actin cosedimentation and immunoprecipitation assays were performed. These methods reveal no direct physical association of SPRR1A with F-actin in the presence or absence of S100C protein (data not shown). Thus, unidentified proteins specific to membrane ruffles must account for the colocalization of F-actin and SPRR1A.

\section{SPRR1A and S100C increase axonal outgrowth in embryonic neurons}

The data indicate that expression of SPRR1A and S100C is correlated with axonal regeneration and that the proteins are colocalized with F-actin. Do SPRR1A and S100C promote axonal regeneration? A functional contribution to axonal regeneration was examined in cultured DRG neurons. Embryonic chick DRG or adult mouse DRG neurons do not express SPRR1A immediately after plating, but high levels develop by $5 \mathrm{~d}$ in vitro (DIV) (Fig. 5A). Induction is much more robust in adult neurons. As seen in tissue sections, the protein is present in axons in which it might directly alter outgrowth. Because E7 chick DRGs do not express the endogenous protein within the first $24 \mathrm{hr}$ in vitro, we examined the effects of SPRR1A introduction into these cells. Infection with an HSV preparation directing SPRR1A expression results in a threefold increase in outgrowth for infected SPRR1A- 
Figure 5. SPRR1A promotes axonal outgrowth in embryonic neurons. $A$, Endogenous SPRR1A protein immunoreactivity is not detected in chick E7 and adult mouse DRGs cultured for 1 DIV but is present after 5 DIV by immunofluorescence. Scale bar, $100 \mu \mathrm{m}$. B, Overexpression of SPRR1A and S100C protein in chick E7 DRGs via recombinant HSV infection increases axonal growth compared with HSV-EGFP-infected cells. EGFP-, SPRR1A-, and S100C-expressing neurons are identified by EGFP fluorescence, SPRR1A immunoreactivity, and S100C immunoreactivity, respectively. $C$, Neurite outgrowth was determined in neurons expressing EGFP, Nogo-66 receptor (NgR, as a control), or SPRR1A via recombinant HSV infection. A significant ( $p \leq 0.05$, Student's two-tailed $t$ test) increase in outgrowth is observed in HSVSPRR1A-infected cultures $24 \mathrm{hr}$ after plating. Data are means \pm SEM from five experiments. $D$, DRG neurons infected with HSV-EGFP or HSV-SPRR1A were cultured on the indicated concentrations of laminin. Mean neurite outgrowth per infected neuron is reported ( \pm SEM). $E$, A significant ( $p \leq 0.05$, Student's twotailed $t$ test) increase in neurite outgrowth HSV Preparation
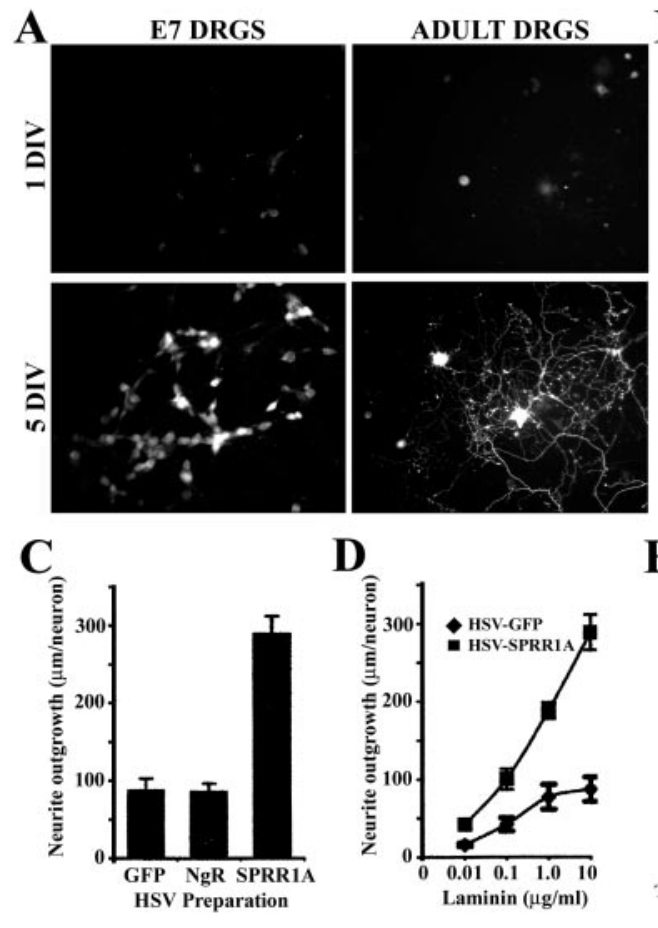
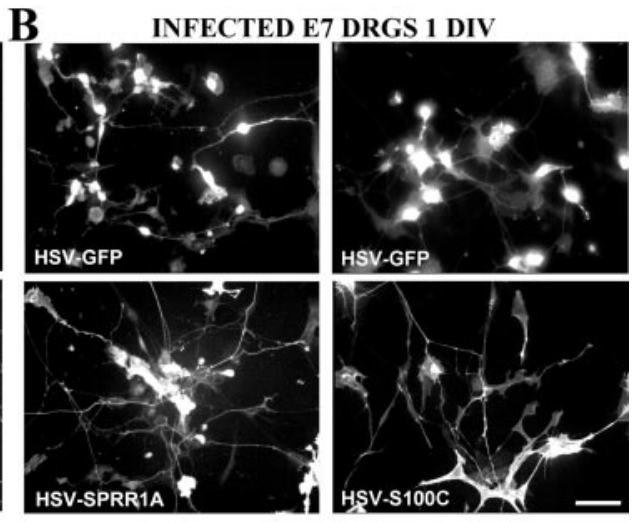

D $\quad$ E
$\mathbf{E}$

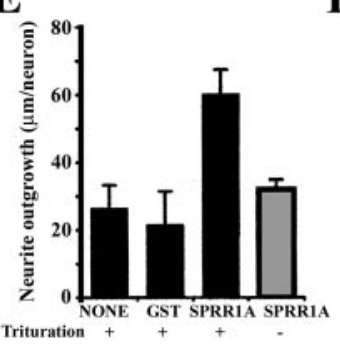

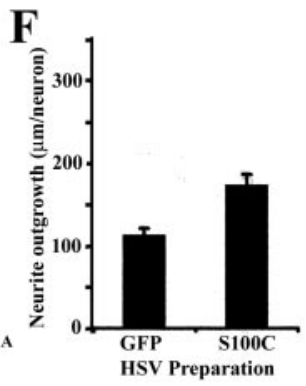

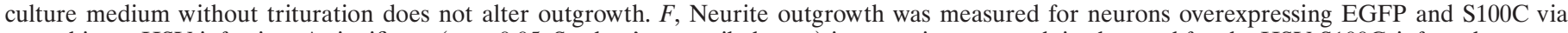

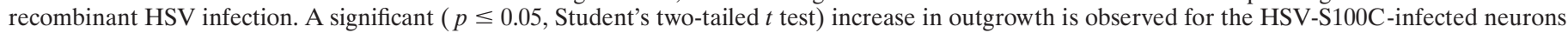
$24 \mathrm{hr}$ after plating.

immunoreactive cells at 1 DIV (Fig. $5 B, C$ ). This appears to alter the intrinsic growth properties of the neurons, and the SPRR1A enhancement of growth is observed over a range of laminin substrate concentrations (Fig. 5D). As an alternative method for increasing SPRR1A levels, recombinant SPRR1A protein was triturated into DRG neurons (Fig. 5E). A similar increase in neurite outgrowth is observed. S100C is normally expressed in embryonic neurons. In recombinant HSV-S100C experiments, overexpression of $\mathrm{S} 100 \mathrm{C}$ results in a moderate $60 \%$ increase in neurite outgrowth (Fig. 5B,F). Thus, neuronal SPRR1A, and to a lesser extent S100C, can directly promote axonal outgrowth.

\section{SPRR1A increases axonal outgrowth in adult neurons}

Although the embryonic neuron experiments demonstrate that SPRR1A can promote axonal growth, studies of adult neurons are more relevant to nerve regeneration. Adult DRG neurons are known to display distinct modes of growth in culture, after peripheral nerve axotomy or removal of the ganglion, with a time-dependent transition from a branching to an elongating mode of outgrowth (Smith and Skene, 1997). Because endogenous SPRR1A is not expressed during the first $24 \mathrm{hr}$ after plating adult mouse DRGs, we sought to determine whether SPRR1A expression altered outgrowth patterns from these neurons. SPRR1A-expressing neurons exhibit an $80 \%$ increase in outgrowth compared with GFP-expressing neurons (Fig. 6A-C). The increase is similar in magnitude to that achieved by a preconditioning axotomy. Axonal branching was decreased $50 \%$ in SPRR1A-expressing neurons compared with GFPexpressing neurons (Fig. 6D). Again, this difference is nearly identical to the decreased branching observed for preconditioned neurons. Thus, acute SPRR1A expression in culture promotes the branching-to-elongating morphological switch and fully mimics the effects of a preconditioning axotomy.

\section{SPRR1A increases axonal outgrowth of embryonic neurons on inhibitory substrates}

In vivo, regenerating neurons frequently encounter inhibitory substrates that limit their outgrowth. Among these inhibitors, CNS myelin containing Nogo may play a role in preventing adult mammalian CNS axon regeneration (GrandPre et al., 2000). Therefore, we sought to determine whether SPRR1A overexpression modulates the sensitivity to these inhibitors. Axonal sensitivity to inhibition by Nogo and CNS myelin is obvious in chick E13 DRG neuronal cultures. Overexpression of SPRR1A has a stimulatory effect on outgrowth over Nogo-66 and CNS myelin but does not overcome the inhibition (Fig. 6E,F). The fractional increase in outgrowth induced by SPRR1A is similar for neurons on laminin, CNS myelin, and Nogo. Thus, SPRR1A expression alters the basal propensity for axonal growth but not the responsiveness to these nonpermissive substrates.

\section{Depletion or blockade of SPRR1A protein decreases outgrowth in adult neurons}

If SPRR1A expression plays a significant role in the regenerative outgrowth of adult neurons, then reduction in SPRR1A activity should reduce axon regeneration. To assess whether SPRR1A is necessary for axonal regeneration, adult DRG neurons were harvested $4 \mathrm{~d}$ after a sciatic nerve transection (preconditioned neurons), and SPRR1A was suppressed by one of two methods. In one protocol, adult DRG neurons were removed and plated for 36 $\mathrm{hr}$ in the presence of sense, antisense, or no oligonucleotide. Western blotting and immunohistochemistry verified that SPRR1A expression was significantly and selectively decreased after treatment with antisense oligonucleotides complimentary to the translation initiation site of the sprr1a sequence (Fig. $7 A-C$ ). 


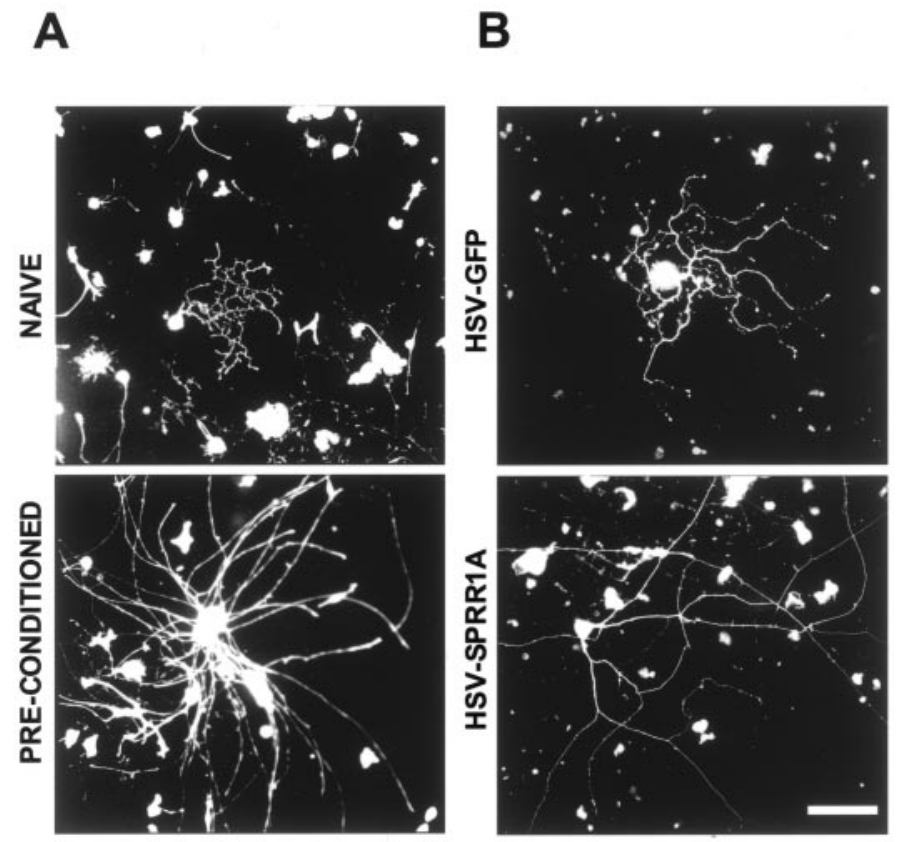

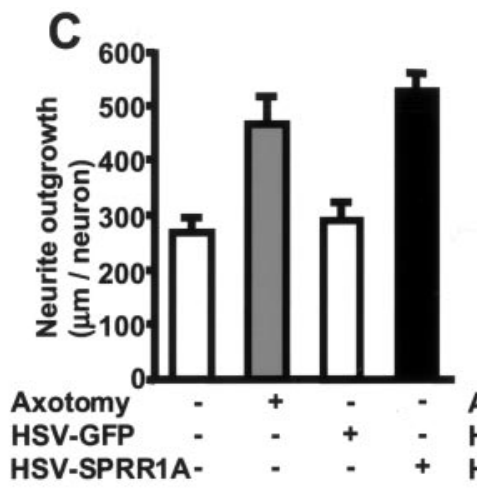

D
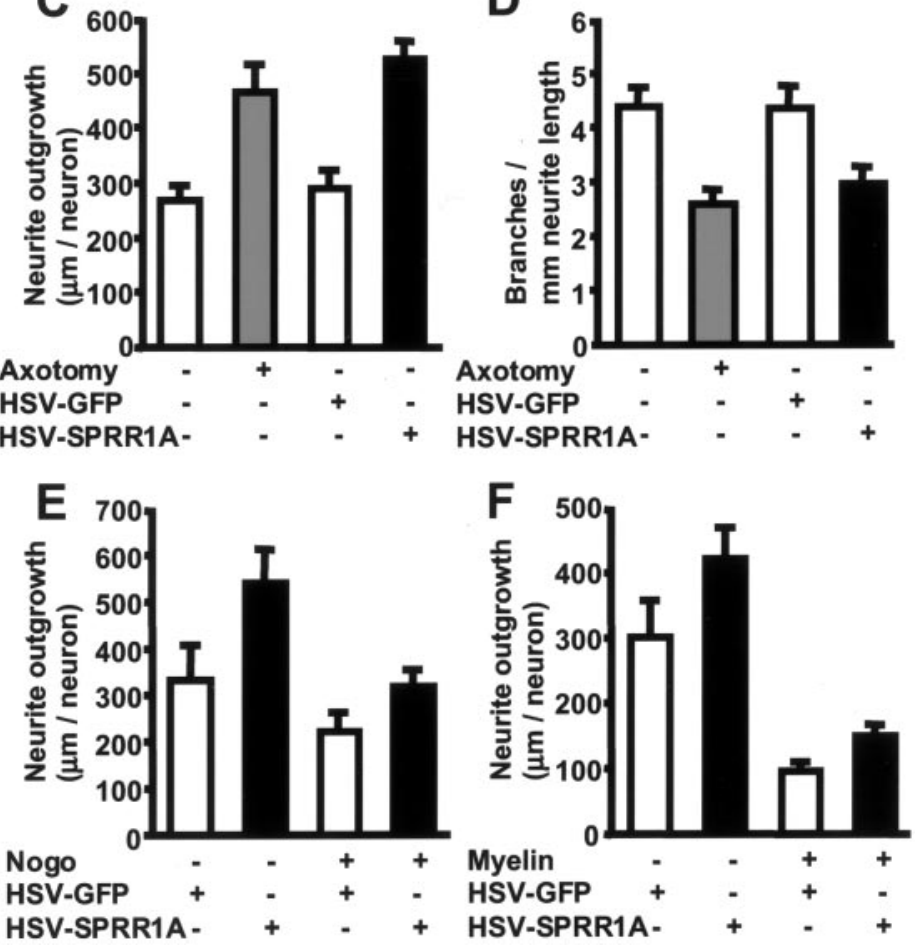

Figure 6. SPRR1A promotes axonal outgrowth in adult neurons and on inhibitory substrates. $A$, Phalloidin staining of adult mouse DRGs after 1 DIV illustrates the different modes of growth that characterize naive and preconditioned neurons. Preconditioned DRGs were removed and plated $4 \mathrm{~d}$ after sciatic nerve axotomy. Whereas naive DRGs extend short and highly branched neurites, preconditioned DRGs grow neurites that are elongated and sparsely branched. $B$, Overexpression of SPRR1A protein in adult mouse DRGs via recombinant HSV infection increases axonal growth and decreases branching compared with HSV-EGFP-infected cells. EGFP- and SPRR1A-expressing neurons are identified by EGFP fluorescence and SPRR1A immunoreactivity, respectively. Scale bar, $100 \mu \mathrm{m}$. $C$, Neurite outgrowth was determined in naive and preconditioned adult mouse DRG neurons (phalloidin staining) and in neurons expressing EGFP (as a control) or SPRR1A via recombinant HSV infection. A significant ( $p \leq 0.05$, Student's two-tailed $t$ test) increase in outgrowth is observed in HSV-SPRR1A-infected cultures $24 \mathrm{hr}$ after plating. Data are means \pm SEM from three experiments. $D$, Axonal branching was calculated for naive and preconditioned neurons and for HSV-EGFP- and HSV-SPRR1A-infected DRGs. We confirmed that preconditioning and HSV-SPRR1A infection significantly ( $p \leq 0.05$, Student's two-tailed $t$ test) decrease branching compared with naive neurons, and a parallel decrease was observed in HSV-SPRR1A-infected DRGs. Data are means \pm SEM from three experiments. E, Neurite outgrowth was measured for HSV-EGFP- and HSV-SPRR1A-infected E13 DRG neurons plated on laminin or GST-Nogo-66 as the substrate. HSV-SPRR1Ainfected neurons exhibit increased outgrowth relative to HSV-EGFP-infected neurons ( $p \leq 0.05$, Student's two-tailed $t$ test) when plated on laminin (10 $\mu \mathrm{g} / \mathrm{ml})$ or on Nogo $\left(34 \mathrm{ng} / \mathrm{mm}^{2}\right)$. Data are means \pm SEM from five experiments. $F$, Neurite outgrowth was measured for HSV-EGFP- and HSV-SPRR1A-infected E13 DRG neurons plated on laminin or bovine CNS myelin as the substrate. HSV-SPRR1A-infected neurons show increased outgrowth compared with HSV-EGFP-infected neurons ( $p \leq 0.05$, Student's two-tailed $t$ test) when plated on laminin (10 $\mu \mathrm{g} / \mathrm{ml})$ or on CNS myelin (45 $\left.\mathrm{ng} / \mathrm{mm}^{2}\right)$. Data are means \pm SEM from five experiments.

Depletion of SPRR1A protein in adult preconditioned neurons with antisense oligonucleotides results in a significant decrease in neurite length (Fig. 7C,D). Antisense-treated preconditioned neurons display outgrowth capabilities that resemble those of naive neurons. Not only is axon outgrowth reduced, but axonal branching indices also show a marked increase in the antisensetreated cultures (Fig. 7E). The lack of effect of these antisense oligonucleotides on the naive neurons that do not express SPRR1A further confirms the selectivity of action.

SPRR1A function was also reduced by trituration of naive and preconditioned adult DRG neurons with affinity-purified SPRR1A antibody. Similar to the antisense oligonucleotide treatment, anti-SPRR1A antibody treatment decreased neurite outgrowth in the adult preconditioned neurons (Fig. $7 F, G$ ). This inhibition was selective in that rabbit $\operatorname{IgG}$ had no effect and anti-SPRR1A-treated naive neurons (lacking SPRR1A) did not exhibit altered outgrowth. Thus, two methods confirm that SPRR1A contributes to the axotomy-induced morphological switch from a branching to an elongating mode of growth.

\section{DISCUSSION}

This expression profile analysis of axotomized sensory neurons highlights the potential role of SPRR1A expression in peripheral axon regeneration. There are several striking aspects to the role of SPRR1A as a regeneration-associated gene: (1) the level of SPRR1A induction by axotomy is extremely high during successful regeneration, (2) SPRR1A is not expressed in uninjured neurons during adulthood or development, (3) sprrla is part of a group of epithelial differentiation genes used during axon regeneration, (4) SPRR1A localizes selectively to actin-rich membrane ruffles, (5) overexpression of SPRR1A alone can produce large increases in neurite extension rates, (6) SPRR1A shifts adult sensory neurons from a branching to an elongating mode of growth, and (7) blockade of SPRR1A decreases the outgrowth potential of preconditioned adult neurons. Together with the observation that axotomized CNS neurons exhibit only very low levels of SPRR1A, these data raise the possibility that exogenous delivery of SPRR1A might be capable of driving adult mammalian CNS axonal regeneration. 
A

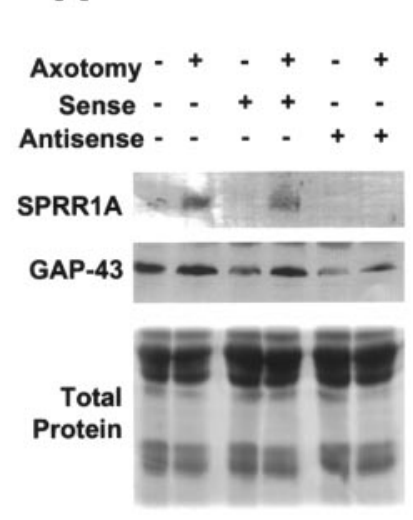

B

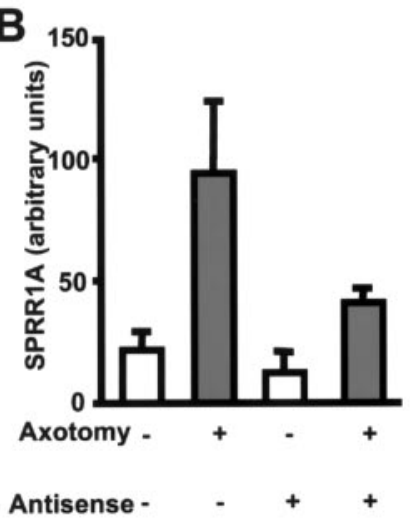

C
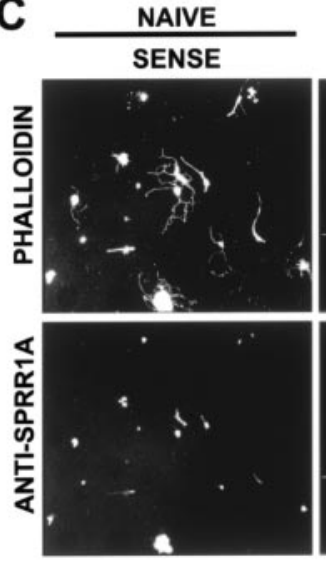

D

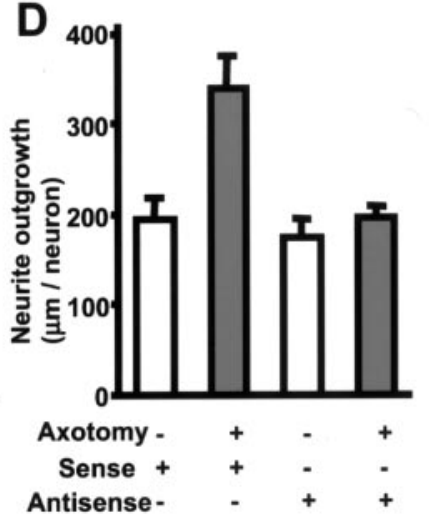

PRE-CONDITIONED
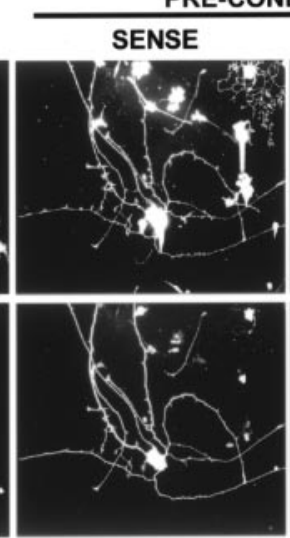

E

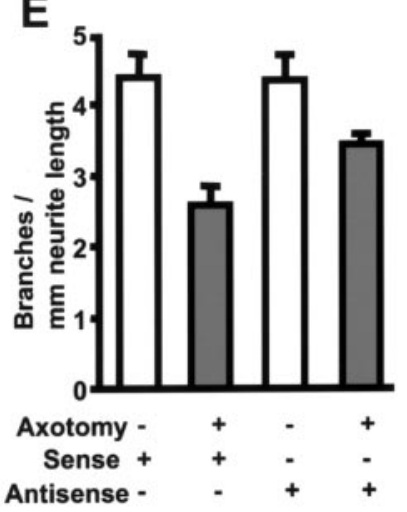

F PRE-CONDITIONED
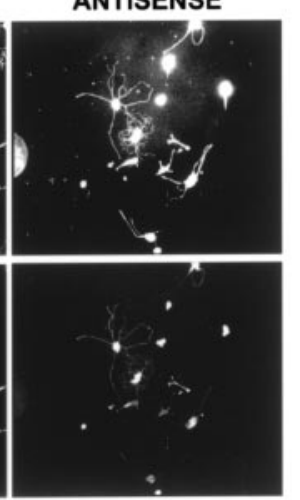
PHALLOIDIN
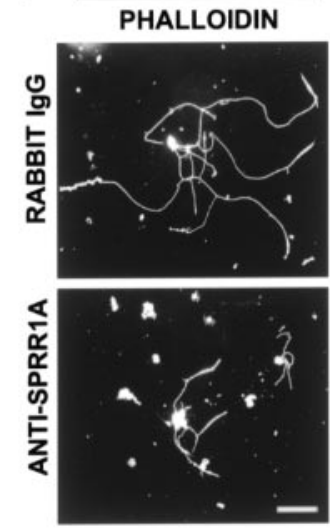

G

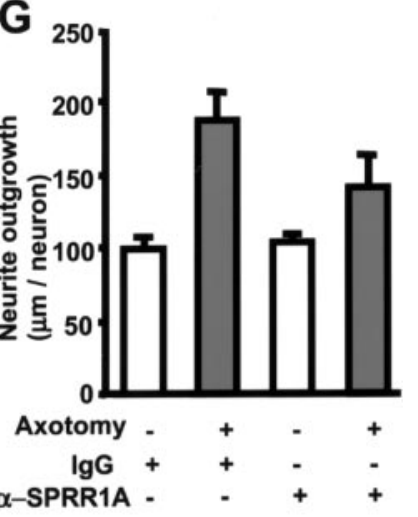

Figure 7. SPRR1A loss of function decreases axonal regeneration in adult DRGs. $A$, Immunoblots for SPRR1A and GAP-43 protein from adult mouse DRG neurons are illustrated. Naive or preconditioned neurons were cultured with sense or antisense oligonucleotides, as indicated. A decrease in SPRR1A immunoreactivity but not in GAP-43 levels is observed after treatment with antisense oligonucleotide. Coomassie brilliant blue staining reveals that total protein levels are equal in all samples. $B$, The SPRR1A signal from immunoblots of control and antisense-treated DRG cultures as in $A$ is quantified. The level of SPRR1A protein decreases to nearly basal levels in neurons treated with antisense oligonucleotide. Data are means \pm SEM from three experiments. $C$, Adult mouse DRG neurons in the naive or preconditioned state were cultured with sense or antisense oligonucleotides. Each vertical pair of panels shows the same field double-labeled with phalloidin to reveal F-actin or with anti-SPRR1A. Naive neurons treated with sense oligonucleotides extend short, branched processes without SPRR1A protein, whereas preconditioned neurons display elongated, less branched axons expressing SPRR1A protein. Preconditioned neurons treated with antisense oligonucleotides exhibit little anti-SPRR1A staining and morphological features similar to those of naive neurons. $D$, Neurite outgrowth was measured for naive and preconditioned neurons treated with either sense or antisense oligonucleotides. A significant ( $p \leq 0.05$, Student's two-tailed $t$ test) decrease in axonal length is observed for antisense oligonucleotide-treated preconditioned neurons compared with sense-treated preconditioned neurons. Data are means \pm SEM from three experiments. E, Axonal branching was determined for naive and preconditioned adult mouse DRG neurons treated with sense or antisense oligonucleotides. For naive neurons, oligonucleotide treatment did not alter branching. For preconditioned neurons, antisense oligonucleotide treatment increased branching compared with sense-treated neurons ( $p \leq 0.05$, Student's two-tailed $t$ test). Data are means \pm SEM from three experiments. $F$, Neurite outgrowth was examined in preconditioned adult neuronal cultures triturated in the presence of rabbit IgG or $\alpha$-SPRR1A. Axonal length was decreased after antibody-mediated blockade of SPRR1A protein compared with rabbit IgG. Scale bar, $100 \mu \mathrm{m}$. $G$, Axonal growth was measured in naive and preconditioned neurons triturated with control antibody, rabbit IgG $(0.2 \mathrm{mg} / \mathrm{ml})$, or affinity-purified SPRR1A antibody $(0.2 \mathrm{mg} / \mathrm{ml})$. Neurite length was decreased in $\alpha$-SPRR1A-triturated preconditioned neurons relative to IgG-treated preconditioned neurons ( $p \leq 0.05$, Student's two-tailed $t$ test). No change in neurite outgrowth was observed in naive neurons triturated with $\alpha$-SPRR1A. Data are means \pm SEM from three experiments.

\section{Microarray analysis of axonal regeneration}

It appears that the sciatic nerve injury paradigm is extremely well suited to expression analysis, for several reasons. First, a single class of neurons is easily obtained by simple dissection of DRGs. There is no issue of variable dissections causing the inclusion of different cell populations. Second, the surgical perturbation is well removed from the neuronal cell body of interest. Thus, inflammatory cell invasion, cell proliferation, and cell death do not alter the cell population under analysis. Third, obtaining adequate amounts of tissue for mRNA analysis is not difficult. All of the differentially expressed genes identified by microarray in our study were confirmed as regulated by axotomy by Northern blot analysis or literature review.
Although the present study extends our understanding of gene expression during axon regeneration, this view is not complete. It should be noted that the microarray screen performed here is far from genome-wide. Furthermore, it is not clear that low-abundance mRNA species are well characterized in this screen, because detectable signals were observed for only $\sim 20 \%$ of the 8500 mRNA species contained on the arrays. Although functional studies have been conducted for SPRR1A and S100C, studies of the other mRNAs induced by nerve regeneration are necessary. Therefore, we suspect that more extensive use of this approach will reveal additional unrecognized molecular mechanisms for axonal regeneration. 


\section{Epithelial differentiation genes and axon regeneration}

It is striking that three of the genes identified in this axon regeneration study were recognized previously as playing a role in epithelial cell differentiation. The derivation of both terminally differentiated keratinizing cells and neurons from neuroectodermal precursors may explain their access to a similar pattern of gene expression after injury. Although both CE formation and axonal regeneration are major morphologic rearrangements, these cellular events have been considered quite distinct, and the overlap in expression profile is unexpected. Examination of other epithelial differentiation markers in axonal regeneration may yield additional parallels between the processes.

The relationship of SPRR1A and S100C is particularly intriguing. Previous epithelial cell studies have demonstrated that both proteins are associated with the differentiation of epithelial cells, cross-linked in the CE, and upregulated after UV irradiation. The present work broadens the list of shared attributes to include increased expression in neurons after peripheral axotomy, colocalization with F-actin in ruffles, colocalization of each with one another, and augmentation of axonal outgrowth. The role of these proteins in epithelial cell differentiation may need to be extended from a structural role in the CE to include modulation of the actin cytoskeleton.

\section{SPRR1A expression in regenerating neurons does not recapitulate development}

The level of SPRR1A induction after peripheral axotomy is extraordinary and supports the notion of its functional role in determining the success of axonal regeneration. Expression of the protein by neurons and localization to axons also support a functional role. Moreover, SPRR1A expression is correlated with successful axonal regeneration in vivo. Both DRG and spinal motor neurons express SPRR1A after axonal injury. In contrast, dorsal column transection leads to only minor elevations of SPRR1A levels in centrally axotomized DRG neurons and to minimal capacity for axonal regeneration. A similar close correlation of the expression of another RAG, GAP-43, with paradigms of successful axonal regeneration has been well documented (Skene and Willard, 1981; Kalil and Skene, 1986; Bomze et al., 2001). The expression pattern suggests that introduction of exogenous SPRR1A after CNS axotomy may promote anatomic and functional recovery.

The absence of SPRR1A expression in developing neurons runs counter to the notion that regeneration recapitulates development. In this regard, SPRR1A is distinct from previously described RAGs, such as GAP-43. It is now clear that the axonregenerative process uses some unique cellular mechanisms compared with nervous system development. Recent signal transduction studies of regenerating neurons support the same view (Liu and Snider, 2001). Additional microarray analysis should lead to a fuller understanding of the similarities and differences between initial axonal extension during the developmental period and later regenerative axon growth.

\section{Mechanism of SPRR1A enhancement of axonal outgrowth}

Overexpression of either SPRR1A or S100C in embryonic DRGs promotes axonal extension. Furthermore, loss of SPRR1A function prevents rapid elongating growth of adult mouse DRG axons in culture. Although we have not examined the central process of preconditioned, injured dorsal column axons, the data suggest that SPRR1A might contribute to their capacity for axon regen- eration. SPRR1A promotion of outgrowth occurs even in embryonic neurons, extending at a rapid rate on laminin in NGF. How might SPRR1A stimulate axonal elongation? The previous epithelial cell literature has focused on a CE cross-linked structural role for SPRR1A. However, we find that transglutaminase activity is not elevated in regenerating neurons and that SPRR1A is not covalently cross-linked under these circumstances. It is also hard to imagine how cross-linking would lead to increased axon extension rates. Therefore, another molecular mechanism accounts for the axon outgrowth-promoting effects of SPRR1A.

The localization of SPRR1A to F-actin-rich structures suggests an alternative mechanism for its action. SPRR1A is found selectively in certain F-actin structures and not others. Leading edge and dorsal membrane ruffles are rich in SPRR1A, whereas lower levels are seen in filopodia, and stress fibers are devoid of SPRR1A. The selective localization implies that SPRR1A stimulates axonal extension by regulating actin-based motility in growth cone ruffles. This fits well with the many studies demonstrating a central role for actin filament dynamics in determining growth cone motility and axonal extension rates (Dickson, 2001). The parallels with S100C also support an actin-regulating role for SPRR1A. S100C binds directly to F-actin and is present in a range of actin-rich structures (Sakaguchi et al., 2000). In ruffles but not stress fibers, SPRR1A and S100C are colocalized with one another and F-actin, suggesting that these coinduced proteins coordinately modulate actin dynamics. Future studies must seek to determine the basis for SPRR1A localization to ruffles. The present work rules out direct S100C or F-actin binding as the basis for this focal accumulation. Although the net effect of SPRR1A expression in axons is to increase extension and to decrease branching, the immediate and relative effect of SPRR1A on different actin structures within the growth cone will require detailed high-magnification, time-resolved analysis.

SPRR1A overexpression, or overexpression of CAP-23 plus GAP-43 (Bomze et al., 2001), can induce a regenerative, elongating mode of axon growth. Although the effect of one or two proteins can be demonstrated with artificial overexpression systems, it is likely that the in vivo regeneration depends on the concerted action of multiple proteins to achieve robust axon growth. Endogenous proregenerative gene expression patterns appear to include SPRR1A, GAP-43, CAP-23, and other RAGs.

This expression profile of peripheral axotomy provides several insights into axonal regeneration and suggests new therapeutic approaches to promoting recovery from CNS axonal injury. The selective expression of SPRR1A during regeneration challenges the link between regeneration and development and establishes a new link between neuronal and epithelial responses to injury. The interaction of SPRR1A with F-actin conforms with current knowledge of the central role of F-actin in growth cone dynamics and suggests a new avenue for modulating axonal growth.

\section{REFERENCES}

Allen BG, Durussel I, Walsh MP, Cox JA (1996) Characterization of the $\mathrm{Ca}^{2+}$-binding properties of calgizzarin (S100C) isolated from chicken gizzard smooth muscle. Biochem Cell Biol 74:687-694.

Bomze HM, Bulsara KR, Iskandar BJ, Caroni P, Skene JH (2001) Spinal axon regeneration evoked by replacing two growth cone proteins in adult neurons. Nat Neurosci 4:38-43.

Chong MS, Woolf CJ, Haque NS, Anderson PN (1999) Axonal regeneration from injured dorsal roots into the spinal cord of adult rats. J Comp Neurol 410:42-54.

Cox LS (1997) Multiple pathways control cell growth and transformation: overlapping and independent activities of p53 and p21Cip1/ WAF1/Sdi1. J Pathol 183:134-140.

Dickson BJ (2001) Rho GTPases in growth cone guidance. Curr Opin Neurobiol 11:103-110. 
Duggan DJ, Bittner M, Chen Y, Meltzer P, Trent JM (1999) Expression profiling using cDNA microarrays. Nat Genet 21:10-14.

Elde R, Cao YH, Cintra A, Brelje TC, Pelto-Huikko M, Junttila T, Fuxe K, Pettersson RF, Hokfelt T (1991) Prominent expression of acidic fibroblast growth factor in motor and sensory neurons. Neuron 7:349-364

El-Deiry WS, Tokino T, Velculescu VE, Levy DB, Parsons R, Trent JM, Lin D, Mercer WE, Kinzler KW, Vogelstein B (1993) WAF1, a potential mediator of p53 tumor suppression. Cell 75:817-825.

Ernfors P, Henschen A, Olson L, Persson H (1989) Expression of nerve growth factor receptor mRNA is developmentally regulated and increased after axotomy in rat spinal cord motoneurons. Neuron 2:1605-1613

Fawcett JW, Asher RA (1999) The glial scar and central nervous system repair. Brain Res Bull 49:377-391.

Fournier AE, Strittmatter SM (2001) Repulsive factors and axon regeneration in the CNS. Curr Opin Neurobiol 11:89-94.

Fournier AE, GrandPre T, Strittmatter SM (2001) Identification of a receptor mediating Nogo-66 inhibition of axonal regeneration. Nature 409:341-346.

Fu SY, Gordon T (1997) The cellular and molecular basis of peripheral nerve regeneration. Mol Neurobiol 14:67-116.

Gartel AL, Tyner AL (1999) Transcriptional regulation of the p21(WAF1/CIP1) gene. Exp Cell Res 246:280-289.

Gibbs S, Fijneman R, Wiegant J, van Kessel AG, van De Putte P, Backendorf C (1993) Molecular characterization and evolution of the SPRR family of keratinocyte differentiation markers encoding small proline-rich proteins. Genomics 16:630-637.

Gillen C, Korfhage C, Muller HW (1997) Gene expression in nerve regeneration. The Neuroscientist 3:112-122.

Gispen WH, Nielander HB, De Graan PN, Oestreicher AB, Schrama LH, Schotman P (1991) Role of the growth-associated protein B-50/ GAP-43 in neuronal plasticity. Mol Neurobiol 5:61-85.

Gonzalez M, Cambiazo V, Maccioni RB (1998) The interaction of Mip-90 with microtubules and actin filaments in human fibroblasts. Exp Cell Res 239:243-253.

Gordon T (1983) Dependence of peripheral nerves on their target organs. In: Somatic and autonomic nerve-muscle interactions (Burnstock G, Vrbova G, O'Brien RA, eds), pp 289-323. New York: Elsevier.

Gorospe M, Wang X, Holbrook NJ (1998) p53-dependent elevation of p21Waf1 expression by UV light is mediated through mRNA stabilization and involves a vanadate-sensitive regulatory system. Mol Cell Biol 18:1400-1407.

Goshima Y, Nakamura F, Strittmatter P, Strittmatter SM (1995) Collapsin-induced growth cone collapse mediated by an intracellular protein related to UNC-33. Nature 376:509-514.

Grafstein B, McQuarrie JG (1978) Role of the nerve cell body in axonal regeneration. In: Neuronal plasticity (Cotman CW, ed), pp 155-196. New York: Raven.

GrandPre T, Nakamura F, Vartanian T, Strittmatter SM (2000) Identification of the Nogo inhibitor of axon regeneration as a reticulon protein. Nature 403:439-444.

Greenberg C, Birckbichler P, Rice R (1991) Transglutaminases: multifunctional cross-linking enzymes that stabilize tissues. FASEB J 5:3071-3077.

Harper JW, Adami GR, Wei N, Keyomarsi K, Elledge SJ (1993) The p21 Cdk-interacting protein Cip1 is a potent inhibitor of G1 cyclindependent kinases. Cell 75:805-816.

Hohl D, de Viragh PA, Amiguet-Barras F, Gibbs S, Backendorf C, Huber M (1995) The small proline-rich proteins constitute a multigene family of differentially regulated cornified cell envelope precursor proteins. J Invest Dermatol 104:902-909.

Jin Z, Strittmatter SM (1997) Rac1 mediates collapsin-1-induced growth cone collapse. J Neurosci 17:6256-6263.

Kalil K, Skene JH (1986) Elevated synthesis of an axonally transported protein correlates with axon outgrowth in normal and injured pyramidal tracts. J Neurosci 6:2563-2570.

Kartasova T, van de Putte P (1988) Isolation, characterization, and UVstimulated expression of two families of genes encoding polypeptides of related structure in human epidermal keratinocytes. Mol Cell Biol 8:2195-2203.

Kartasova T, van Muijen GN, van Pelt-Heerschap H, van de Putte P (1988) Novel protein in human epidermal keratinocytes: regulation of expression during differentiation. Mol Cell Biol 8:2204-2210.

Katz F, Ellis L, Pfenninger KH (1985) Nerve growth cones isolated from fetal rat brain. III. Calcium-dependent protein phosphorylation. J Neurosci 5:1402-1411.

Kiryu S, Yao GL, Morita N, Kato H, Kiyama H (1995) Nerve injury enhances rat neuronal glutamate transporter expression: identification by differential display PCR. J Neurosci 15:7872-7878.

Kobayashi NR, Bedard AM, Hincke MT, Tetzlaff W (1996) Increased expression of BDNF and trkB mRNA in rat facial motoneurons after axotomy. Eur J Neurosci 8:1018-1029.

Krekoski CA, Parhad IM, Clark AW (1996) Attenuation and recovery of nerve growth factor receptor mRNA in dorsal root ganglion neurons following axotomy. J Neurosci Res 43:1-11.

Liu RY, Snider WD (2001) Different signaling pathways mediate regenerative versus developmental sensory axon growth. J Neurosci 21:RC164:1-5.

Luo ZD, Chaplan SR, Higuera ES, Sorkin LS, Stauderman KA, Williams ME, Yaksh TL (2001) Upregulation of dorsal root ganglion $\alpha 2 \delta$ calcium channel subunit and its correlation with allodynia in spinal nerveinjured rats. J Neurosci 21:1868-1875.

Mailliard WS, Haigler HT, Schlaepfer DD (1996) Calcium-dependent binding of S100C to the N-terminal domain of annexin I. J Biol Chem $271: 719-725$.

Marchionni MA, Goodearl AD, Chen MS, Bermingham-McDonogh O, Kirk C, Hendricks M, Danehy F, Misumi D, Sudhalter J, Kobayashi K (1993) Glial growth factors are alternatively spliced erbB2 ligands expressed in the nervous system. Nature 362:312-318.

Marti T, Erttmann KD, Gallin MY (1996) Host-parasite interaction in human onchocerciasis: identification and sequence analysis of a novel human calgranulin. Biochem Biophys Res Commun 221:454-458.

Moskowitz PF, Oblinger MM (1995) Sensory neurons selectively upregulate synthesis and transport of the $\beta$ III-tubulin protein during xonal regeneration. J Neurosci 15:1545-1555.

Muma NA, Hoffman PN, Slunt HH, Applegate MD, Lieberburg I, Price DL (1990) Alterations in levels of mRNAs coding for neurofilament protein subunits during regeneration. Exp Neurol 107:230-235.

Naka M, Qing ZX, Sasaki T, Kise H, Tawara I, Hamaguchi S, Tanaka T (1994) Purification and characterization of a novel calcium-binding protein, S100C, from porcine heart. Biochim Biophys Acta 1223:348-353.

Nakamura F, Tanaka M, Takahashi T, Kalb RG, Strittmatter SM (1998) Neuropilin-1 extracellular domains mediate semaphorin D/III-induced growth cone collapse. Neuron 21:1093-1100.

Naveilhan P, ElShamy WM, Ernfors P (1997) Differential regulation of mRNAs for GDNF and its receptors Ret and GDNFR alpha after sciatic nerve lesion in the mouse. Eur J Neurosci 9:1450-1460.

Neumann S, Woolf CJ (1999) Regeneration of dorsal column fibers into and beyond the lesion site following adult spinal cord injury. Neuron 23:83-91.

Nielsch U, Keen P (1989) Reciprocal regulation of tachykinin- and vasoactive intestinal peptide-gene expression in rat sensory neurones following cut and crush injury. Brain Res 481:25-30.

Robinson NA, Lapic S, Welter JF, Eckert RL (1997) S100A11, S100A10, annexin I, desmosomal proteins, small proline-rich proteins, plasminogen activator inhibitor-2, and involucrin are components of the cornified envelope of cultured human epidermal keratinocytes. J Biol Chem 272:12035-12046.

Rosen CF, Poon R, Drucker DJ (1995) UVB radiation-activated genes induced by transcriptional and posttranscriptional mechanisms in rat keratinocytes. Am J Physiol 268:C846-C855.

Sakaguchi M, Miyazaki M, Inoue Y, Tsuji T, Kouchi H, Tanaka T, Yamada H, Namba M (2000) Relationship between contact inhibition and intranuclear S100C of normal human fibroblasts. J Cell Bio 149:1193-1206

Sasahara M, Fries JW, Raines EW, Gown AM, Westrum LE, Frosch MP, Bonthron DT, Ross R, Collins T (1991) PDGF B-chain in neurons of the central nervous system, posterior pituitary, and in a transgenic model. Cell 64:217-227.

Schecterson LC, Bothwell M (1992) Novel roles for neurotrophins are suggested by BDNF and NT-3 mRNA expression in developing neurons. Neuron 9:449-463.

Schnell L, Schneider R, Kolbeck R, Barde YA, Schwab ME (1994) Neurotrophin-3 enhances sprouting of corticospinal tract during development and after adult spinal cord lesion. Nature 367:170-173.

Scotto C, Deloulme JC, Rousseau D, Chambaz E, Baudier J (1998) Calcium and S100B regulation of p53-dependent cell growth arrest and apoptosis. Mol Cell Biol 18:4272-4281.

Skene JH (1989) Axonal growth-associated proteins. Annu Rev Neurosci $12: 127-156$

Skene JH, Willard M (1981) Axonally transported proteins associated with axon growth in rabbit central and peripheral nervous systems. J Cell Biol 89:96-103.

Smith DS, Skene JH (1997) A transcription-dependent switch controls competence of adult neurons for distinct modes of axon growth. J Neurosci 17:646-658.

Stoll G, Griffin JW, Li CY, Trapp BD (1989) Wallerian degeneration in the peripheral nervous system: participation of both Schwann cells and macrophages in myelin degradation. J Neurocytol 18:671-683.

Su QN, Namikawa K, Toki H, Kiyama H (1997) Differential display reveals transcriptional up-regulation of the motor molecules for both anterograde and retrograde axonal transport during nerve regeneration. Eur J Neurosci 9:1542-1547.

Takahashi T, Nakamura F, Jin Z, Kalb RG, Strittmatter SM (1998) Semaphorins A and E act as antagonists of neuropilin-1 and agonists of neuropilin-2 receptors. Nat Neurosci 1:487-493.

Takahashi T, Fournier A, Nakamura F, Wang LH, Murakami Y, Kalb 
RG, Fujisawa H, Strittmatter SM (1999) Plexin-neuropilin-1 complexes form functional semaphorin-3A receptors. Cell 99:59-69.

Tanabe K, Nakagomi S, Kiryu-Seo S, Namikawa K, Imai Y, Ochi T, Tohyama M, Kiyama H (1999) Expressed-sequence-tag approach to identify differentially expressed genes following peripheral nerve axotomy. Brain Res Mol Brain Res 64:34-40.

Tanabe K, Tachibana T, Yamashita T, Che YH, Yoneda Y, Ochi T, Tohyama M, Yoshikawa H, Kiyama H (2000) The small GTP-binding protein TC10 promotes nerve elongation in neuronal cells, and its expression is induced during nerve regeneration in rats. $\mathrm{J}$ Neurosci 20:4138-4144.

Troy CM, Muma NA, Greene LA, Price DL, Shelanski ML (1990) Regulation of peripherin and neurofilament expression in regenerating rat motor neurons. Brain Res 529:232-238.

Villar MJ, Cortes R, Theodorsson E, Wiesenfeld-Hallin Z, Schalling M, Fahrenkrug J, Emson PC, Hokfelt T (1989) Neuropeptide expression in rat dorsal root ganglion cells and spinal cord after peripheral nerve injury with special reference to galanin. Neuroscience 33:587-604.

Wakisaka S, Kajander KC, Bennett GJ (1991) Increased neuropeptide Y (NPY)-like immunoreactivity in rat sensory neurons following peripheral axotomy. Neurosci Lett 124:200-203.
Wilkinson DG, Nieto MA (1993) Detection of messenger RNA by in situ hybridization to tissue sections and whole mounts. Methods Enzymol 225:361-373.

Wong J, Oblinger MM (1990) Differential regulation of peripherin and neurofilament gene expression in regenerating rat DRG neurons. J Neurosci Res 27:332-341.

Xiong Y, Hannon GJ, Zhang H, Casso D, Kobayashi R, Beach D (1993) p21 is a universal inhibitor of cyclin kinases. Nature 366:701-704.

Yeh HJ, Ruit KG, Wang YX, Parks WC, Snider WD, Deuel TF (1991) PDGF A-chain gene is expressed by mammalian neurons during development and in maturity. Cell 64:209-216.

Zeng YX, Somasundaram K, El-Deiry WS (1997) AP2 inhibits cancer cell growth and activates p21WAF1/CIP1 expression. Nat Genet $15: 78-82$.

Zhang Q, Shi TJ, Ji RR, Zhang YZ, Sundler F, Hannibal J, Fahrenkrug J, Hokfelt T, Zhang Y (1995) Expression of pituitary adenylate cyclase-activating polypeptide in dorsal root ganglia following axotomy: time course and coexistence. Brain Res 705:149-158.

Zigmond RE, Hyatt-Sachs H, Mohney RP, Schreiber RC, Shadiack AM, Sun Y, Vaccariello SA (1996) Changes in neuropeptide phenotype after axotomy of adult peripheral neurons and the role of leukemia inhibitory factor. Perspect Dev Neurobiol 4:75-90. 